Estudios Constitucionales, Año 8, No 2, 2010, pp. 201 - 246.

ISSN 0718-0195

Centro de Estudios Constitucionales de Chile Universidad de Talca

"Tutela judicial de graves violaciones a los derechos humanos: las actuaciones del juez y las omisiones del legislador chileno”

Liliana Galdámez Zelada

\title{
TUTELA JUDICIAL DE GRAVES VIOLACIONES A LOS DERECHOS HUMANOS: LAS ACTUACIONES DEL JUEZ Y LAS OMISIONES DEL LEGISLADOR CHILENO
}

\author{
JUDICIAL PROTECTION OF THE SERIOUS VIOLATIONS \\ OF HUMAN RIGHTS: PROCEEDINGS OF THE COURT AND \\ OMISSIONS OF CHILEAN LEGISLATURE
}

\author{
LILIANA GALDÁMEZ ZELADA ${ }^{1}$ \\ Doctora en Derecho, Universidad de Valladolid \\ galdamez@der.uva.es
}

RESUMEN: Si bien en la jurisprudencia nacional se ha instalado como criterio dominante la inaplicabilidad de la amnistía y la prescripción en casos de desaparición forzada, tortura y ejecuciones extralegales, este consenso no se ha logrado en lo que se refiere a la responsabilidad extracontractual derivada de estos crimenes, ni en cuanto a las penas aplicables a sus responsables.

Los desarrollos elaborados por los jueces, los problemas dogmáticos que han debido sortear y los ámbitos donde todavía se observan criterios pendulares pueden ser analizados desde varias perspectivas, algunas de ellas menos exploradas por la doctrina. En este trabajo se prestará especial atención a los problemas que ha planteado el poder legislativo para desarrollar normas generales en este ámbito y las consecuencias de su inactividad para el tratamiento de los derechos en juego.

ABSTRACT: If the inapplicability of amnesty and statute limitation in the case of forced disappearance, torture and extralegal executions has indeed established itself as a dominant criterion of national jurisprudence, this consensus has not been attained as regards extracontractual responsibility derived from these crimes, nor in respect of the punishment dealt to those responsible.

The developments brought about by judges, the dogmatic problems which have been avoided and the areas where swinging criteria still apply, can be analyzed from diverse perspectives, some of which have yet to be explored in depth by the doctrine. In this piece of work special attention will be paid to the problems set out by the legislative authority in order to develop general norms in this area and the consequences of their inactivity in dealing with the rights in question.

PALABRAS CLAVE: Violaciones graves a los derechos humanos, amnistía, prescripción, principio de legalidad penal, omisiones del legislador.

KEY WORDS: Serious violations of human rights. Amnesty. Statute limitation. Legal penal principle. Legislative omissions.

\footnotetext{
${ }^{1}$ Este artículo forma parte del trabajo de investigación para acceder al grado de Doctora y que fue reconocido en noviembre de 2009. Recibido el 21 de mayo de 2010 y aprobado el 22 de septiembre de 2010.
} 


\section{ESTADO DE LA CUESTIÓN}

La doctrina nacional reconoce la consolidación jurisprudencial de la tutela judicial de las violaciones graves a los derechos humanos a partir del año 2004, cuando se dictó la sentencia del caso por la desaparición forzada de Miguel Ángel Sandoval ${ }^{2}$. A partir de esta sentencia los jueces se han inclinado mayoritariamente por declarar la inaplicabilidad de la amnistía y la prescripción en estos casos.

Como en todo el entorno latinoamericano, han sido primero los jueces en elaborar y aplicar criterios para poner límites a las leyes de amnistía y a la extinción de la responsabilidad penal por el transcurso del tiempo. Pero en el caso chileno -a diferencia de lo que ocurre en Argentina-, el legislador se ha opuesto a dictar normas en este sentido. En efecto, en Argentina, el 22 de diciembre de 1983 se dictó la Ley No 23.040 que derogó la ley de autoamnistía, también la Ley No 24.952 de 25 de marzo de 1998, que derogó las leyes de punto final y obediencia debida y más adelante, la Ley No 25.779, de 21 de agosto de 2003, las declaró insanablemente nulas. Ninguna ley de contenido similar se ha dictado en Chile.

La omisión del legislador en esta materia trae consecuencias contraproducentes en el tratamiento de los derechos fundamentales; subsisten todavía ámbitos donde no se aprecia un criterio definitivo y donde la jurisprudencia es pendular. Estos problemas requieren de una solución general y es en este sentido que hace falta la intervención del legislador.

En las actuaciones del juez, los tratados internacionales juegan un rol central y el ya clásico debate sobre su jerarquía en el ordenamiento interno -aunque ahora más superado- contribuye a que la mayoría de los legisladores se niegue a dar desarrollo normativo a las obligaciones que contienen, especialmente cuando estos compromisos afectan a hechos ocurridos en nuestro pasado.

Existe un contexto al que debemos hacer referencia para comprender todas las dificultades que este deber ha supuesto en el ordenamiento nacional.

\section{EL CONTEXTO EN QUE SE PRODUJERON LAS VIOLACIONES \\ A LOS DERECHOS HUMANOS}

En Chile, las violaciones graves a los derechos humanos sólo han sido investigadas, juzgadas y sancionadas en democracia. Cuando estos crímenes ocurrieron el país estaba sometido a un régimen de facto distinto de aquél bajo el cual estos hechos se han juzgado. Si se pudiera ver esta secuencia en el tiempo, quedaría en evidencia la siguiente situación:

\footnotetext{
${ }^{2}$ En este sentido: Matus (2006) pp. 275-296.
} 


\begin{tabular}{|c|c|c|c|}
\hline 1980 & 1989 & 1998 & 2005 \\
\hline Constitución 80 & $\begin{array}{l}\text { Transición a la } \\
\text { democracia }\end{array}$ & $\begin{array}{l}\text { Detención } \\
\text { Pinochet }\end{array}$ & Reforma \\
\hline $\begin{array}{l}\text { Reformas } \\
\text { Constitucionales }\end{array}$ & $\begin{array}{l}\text { Nueva } \\
\text { jurisprudencia }\end{array}$ & & $\begin{array}{l}\text { Nuevos tratados } \\
\text { Sanción de esas } \\
\text { violaciones }\end{array}$ \\
\hline
\end{tabular}

Las dificultades dogmáticas que ha supuesto el desarrollo del deber de prevenir, juzgar y sancionar crímenes de guerra y de lesa humanidad, no pueden ser explicadas si esta brecha en el tiempo no es considerada.

Además, a las transformaciones del ordenamiento jurídico nacional se agrega el mayor desarrollo del Derecho Internacional en tres vertientes: el Derecho Internacional de los Derechos Humanos, el Derecho Internacional Humanitario y, más recientemente, el Derecho Penal Internacional que también han incidido en los ordenamientos nacionales a través de cláusulas de apertura constitucional al Derecho Internacional.

Asimismo, la aplicación de las normas del ius cogens, concebidas como normas imperativas e inexcusables para los Estados, han incorporado nuevos elementos que, dada su naturaleza jurídica, hacen el análisis todavía más complejo.

La brecha temporal que separa los hechos de su juzgamiento y sanción, no puede ser entendida si no se analiza el contexto en el que ocurrieron esas violaciones, si no se considera que cuando ellas se produjeron no existía un Estado de Derecho que respetara los derechos, que los protegiera, ni castigara su vulneración.

El contexto político y la normativa jurídica que rigió en Chile entre 1973 y 1990, es asimilable a lo que Kai Ambos ha llamado el contexto de la macrocriminalidad. Esta noción hace referencia a la estructura de un poder organizado para reprimir al adversario, que se vale de ese control para procurar la impunidad de actos atroces y que ha eliminado o hecho imposible la activación de mecanismos jurídicos que procuren la defensa o protección de los derechos vulnerados.

En Chile, a partir de 1973, se restringieron sistemáticamente las garantías y libertades individuales. Mediante la reiterada y sucesiva declaración del Estado de Sitio y otros estados de excepción constitucional, varios derechos individuales fundamentales fueron suprimidos ${ }^{3}$. La normativa de excepción constitucional generó la indefensión de los ciudadanos frente al poder político y militar radicado en la Junta de Gobierno.

Según cifras del Ministerio del Interior, durante la dictadura se registraron 1.183 casos de personas detenidas y desaparecidas, 2.008 personas fueron eje-

\footnotetext{
${ }^{3}$ Informe País (1985) Comisión de Derechos Humanos de la Organización de Estados Americanos.
} 
cutadas por razones políticas. En cuanto a tortura, el informe de la Comisión Nacional sobre Presión Política y Tortura, registró un total de 35.868 denuncias por torturas ocurridas entre 1973 y 1990.

A partir del 11 de septiembre de 1973, la Junta Militar asumió "el Mando Supremo de la Nación" ". La Constitución de 1925 adquirió un carácter subsidiario y se gobernó a través de bandos militares y decretos leyes. El informe especial de la Comisión Interamericana de Derechos Humanos de 1974, señaló que a partir del golpe militar se creó un nuevo sistema normativo: el D.L. No 1 señaló que la Junta Militar "garantizará la plena eficacia de las atribuciones del poder judicial" y respetaría "la Constitución y las leyes de la República en la medida que la actual situación del país lo permita para el mejor cumplimiento de los postulados que ella se propone". El mismo 11 de septiembre la Junta, invocando el art. 72 No 17 de la Constitución y el Código de Justicia Militar, decretó el Estado de sitio en todo el territorio nacional.

Los historiadores Simon Collier y Wiliam F. Sater describen un lúcido retrato de la época, "La mano dura de una represión inclemente golpeó de inmediato después del golpe. Se cerró el Congreso. Los partidos de la UP fueron prohibidos; otros declarados 'en receso' (hasta 1977, cuando también fueron prohibidos). Se impuso un estricto toque de queda nocturno que duró varios años. Los periódicos y las revistas de izquierda desaparecieron de los quioscos. La administración pública fue purgada concienzudamente. En la etapa inicial del régimen, prácticamente todas las instituciones nacionales importantes (incluida la Federación de fútbol) quedaron en manos de oficiales militares o navales, algunos de ellos que ya estaban en retiro y fueron llamados de nuevo al servicio. Uniformados 'rectores designados' fueron puestos a la cabeza de las Universidades (también purgadas con minuciosidad). De la noche a la mañana, la atmósfera de Chile se volvió transformada. El primer ministro del Interior del régimen, general Óscar Bonilla... replicó a un sindicalista del comercio que lo visitaba en su oficina: Deje de usar la palabra exigencia; no se olvide que esta es una dictadura'. Nadie podría haberlo expresado mejor"s.

En este orden de cosas, cabe preguntarse el papel del poder judicial frente a estas disposiciones y actuaciones. El informe de la CIDH de 1985 señaló que las facultades legislativas y constituyentes que la Junta se autoadjudicó, afectaron visiblemente la independencia del poder judicial. En primer lugar, por el traspaso a la jurisdicción militar de la mayoría de los procesos por violaciones a los derechos humanos y, en segundo lugar, porque el Poder Judicial autolimitó sus propias

${ }^{4}$ D.L. No 1,1973 , artículo $1^{\circ}$.

${ }^{5}$ Collier-Sater (1998) p. 307. 
facultades ejerciendo formalmente sus funciones, pero eludiendo el conocimiento de los hechos que le eran sometidos. A mayor abundamiento, "Según información proporcionada a la CIDH, entre septiembre de 1973 y diciembre de 1983, el Comité de Cooperación para la Paz en Chile y luego la Vicaría de la Solidaridad asesoraron la interposición de 5.400 recursos de amparo... en favor de personas arrestadas por orden de la autoridad política o que sufrieron perturbaciones en su derecho a la libertad personal. De toda esta cantidad de recursos, los tribunales sólo acogieron 10, en muy pocos de los cuales se logró la libertad del afectado...”.

Por otra parte, el 18 de abril de 1978 mediante Decreto Ley No 2.191, la Junta de Gobierno ejerciendo su poder como legislador publicó la Ley de Amnistía, que en el futuro se convirtió en un tema central del debate y en un obstáculo para abordar el problema de la justicia, como en muchos países de la región. La aplicación de la Ley de Amnistía trajo como consecuencia que durante la dictadura y los primeros años de la transición los jueces se negaran, casi sistemáticamente, a investigar las denuncias por violaciones a los derechos humanos ocurridas entre 1973 y 1978.

Con la transición a la democracia el Poder Judicial fue objeto de una crítica tenaz por el rol que jugó durante la dictadura. Todo ello fue importante para su transformación, que se produjo también por el relevo generacional, y que incidió favorablemente en su apertura paulatina hacia la aplicabilidad de instrumentos internacionales de derechos humanos y cuyo resultado más visible es el procesamiento y encarcelamiento de varios ex altos mandos del Ejército y de la policía secreta del general Pinochet.

Han sido los tratados sobre derechos humanos ratificados por el país y las normas del ius cogens las principales normas en las que se han apoyado los jueces para juzgar y castigar las violaciones graves ocurridas durante la dictadura, tratados que han sido considerados de aplicación preferente en el ordenamiento interno. La vinculación entre el desarrollo de este deber y el artículo 5.2 de la Constitución ha sido la llave normativa para juzgar y sancionar estos crímenes.

\section{LA POLÉMICA JURÍDICA}

La doctrina chilena ha debatido los últimos 20 años sobre la eficacia constitucional de los tratados en el ordenamiento interno. Durante los primeros años la discusión se centró en el rango de los tratados y, más recientemente, en la jerarquía o posición de los derechos esenciales que ellos contienen.

Las opiniones de la doctrina en relación al inciso segundo del artículo $5^{\circ}$ de la Constitución -polémica a la que no me referiré en detalle por ser de sobra co- 
nocida-, configuran básicamente tres corrientes: la primera, que es mayoritaria, defiende la tesis del rango constitucional de los derechos esenciales contenidos en tratados ratificados y vigentes ${ }^{6}$, dentro de esta corriente existen algunos matices que dan mayor o menor amplitud a este reconocimiento, por ejemplo, el profesor Humberto Nogueira sostiene la vigencia del bloque constitucional de derechos en nuestro ordenamiento ${ }^{7}$; la segunda, que dirige su análisis al rango de los tratados, que defiende el profesor Lautaro Ríos, les atribuye jerarquía supralegal o incluso legal y considera que la reforma reforzó el sistema de derechos: les dio énfasis. En cuanto a esta tesis, la principal crítica que se le ha planteado es que no concede efecto útil a la reforma, ni explica cómo ni de qué manera estos derechos resultarían fortalecidos ${ }^{8}$. La tercera tesis sostiene que la redacción de la norma no es concluyente y que habrá de analizarse las interpretaciones que los jueces y el Tribunal Constitucional han hecho en esta materia?.

Comparto la opinión de los autores que sostienen que dirigir la discusión exclusivamente al ámbito de la jerarquía de los tratados es inadecuado porque la referencia del artículo 5, no es al tratado en su conjunto, es a los derechos esenciales que ellos contienen. Pero no coincido con esta corriente cuando defiende la existencia de derechos fundamentales totalmente desconectados de la Constitución y creados sólo y exclusivamente desde los tratados internacionales. Incluso desde la lógica de los derechos implícitos en la Constitución, que nuestro Tribuna Constitucional ha reconocido en algunos $\operatorname{casos}^{10}$, los nuevos derechos se configuran a partir de normas y principios contenidos en la Constitución en relación a los derechos desarrollados, por ejemplo, en la Convención Americana de Derechos Humanos ${ }^{11}$. Cierto es, que esta lógica permite un enorme desarrollo, más aún cuando es la dignidad humana el fundamento sobre el que se configura un derecho.

\footnotetext{
${ }^{6}$ Varios autores: (Silva Bascuñán, 1997, p. 111; Mohor, 1990, pp. 53-193; Medina, 1993; Cumplido Cereceda, 2003, pp. 365-374; CeA, 1997, p. 81).

${ }^{7}$ Nogueira (2007) p. 42.

${ }^{8}$ Ríos (1998) pp. 7-14.

${ }^{9}$ Son partidarios de esta corriente, entre otros: OrRego VicuÑa, Francisco (1998); Infante (1996) pp. 277 297.

${ }^{10}$ Tribunal Constitucional, Rol No 226 (1995) sobre Constitucionalidad del proyecto de Ley sobre "Libertad de expresión, información y ejercicio del periodismo". Más recientemente, Tribunal Constitucional Rol No 1.340-09 (2009) sobre protección del Derecho a la identidad.

${ }^{11}$ En la doctrina española también se ha debatido acerca de la posibilidad de que existan derechos totalmente desconectados de los que la Constitución admite. Sobre este debate vid.: SaIz ArnaIz (1999) p. 79.

También se ha pronunciado el TCE, STC 84/1989.
} 
El debate que se ha producido en torno al 5.2 de la Constitución coloca en el centro de las reflexiones la jerarquía de los derechos de tratados y esta posición plantea algunos problemas que derivan de la escasa regulación de los tratados en la Constitución; de las dificultades que supone sostener que por vía del artículo 5.2 se ha establecido un mecanismo de reforma constitucional distinto del que contiene el Capítulo XV, y de la ausencia de mecanismos de protección para los nuevos derechos. Sin embargo, por las razones que se expondrán en el siguiente apartado, estas críticas no nos conducen a defender la tesis planteada por Lautaro Ríos.

No nos sumamos a esta tesis, entre otras razones porque, como opina Humberto Nogueira, dicho planteamiento niega efecto útil a la reforma. En efecto, esta corriente se limita a sostener la posición infraconstitucional de los tratados, agregando que la norma coloca un énfasis en los derechos constitucionales, pero no dice cómo, de qué manera y con qué efectos concretos.

En este trabajo se propone la tesis de los derechos de tratado como canon para la interpretación de los derechos, que no supone alterar la ubicación de los tratados en el ordenamiento interno, que tendrían formalmente una posición infraconstitucional, pero que permitirían la reintegración de los derechos contenidos de forma explícita e implícita en la Constitución.

En la proposición de los derechos de tratado como canon hermenéutico, que la doctrina española ha abordado en profundidad, se ha reflexionado acerca de la posibilidad de que por vía de los tratados ingresen nuevos derechos al ordenamiento interno y se ha concluido que esta hipótesis no tendría cabida en el ordenamiento español. De lo examinado hasta ahora, no se han encontrado casos en la jurisprudencia de los tribunales chilenos que contradigan esta lógica. Incluso en una sentencia más reciente del Tribunal Constitucional chileno donde se reconoce el derecho a la identidad, Rol No 1.340-09 de 29 de septiembre de 2009, este derecho se reconoce por ser un derecho implícito en la Constitución, en la Convención Americana de Derechos Humanos (artículo 18); en el PIDCP (artículo 24.2), y en la Convención sobre Derechos del Niño (artículo 7 o numerales 1 y 2).

De ser admisible en Chile el reconocimiento de nuevos derechos sin conexión con la Constitución, uno de los problemas que plantea la tesis de la jerarquía constitucional, es que no existen normas que extiendan garantías constitucionales para esos nuevos derechos, especialmente, en lo que se refiere al recurso de protección. En Chile, el tratamiento que ha dado la jurisprudencia a los derechos de tratado se ha hecho en conexión a los derechos y principios reconocidos en la Constitución, tanto en la medida en que se desarrollan nuevos contenidos o como si se delimita el derecho. Este mecanismo ha operado a través de la relación entre la norma nacional y la norma internacional. 
Más aún, en el caso del Tribunal Constitucional su jurisprudencia más reciente, si bien ha admitido esta posibilidad en términos teóricos, ha preferido no concretar ese planteamiento en el reconocimiento de un nuevo derecho esencial proveniente única y exclusivamente de un tratado.

La crítica de un sector de la doctrina que sostiene que si por el inciso segundo del artículo $5^{\circ}$ se incorporan nuevos derechos, por tanto, que se establecería un mecanismo secundario de reforma constitucional, pierde validez en la tesis que se ha planteado.

Asimismo, la jurisprudencia aporta más elementos al análisis, y sin decirlo de forma expresa, ha utilizado los derechos de tratados y las normas del ius cogens para interpretar los derechos que la Constitución reconoce, porque como señala la profesora Irigoin ${ }^{12}$, la aplicación de normas de tratado en la jurisprudencia se ha asociado al derecho nacional ${ }^{13}$.

Antes de analizar los tratados desde la lógica de su jerarquía, el análisis desde su valor y obligaciones permite otras opciones al intérprete ${ }^{14}$. Especialmente, si los tratados contribuyen a delimitar estos derechos, a descubrir nuevos ámbitos o a delimitar su alcance. Sí se admite que los tratados de derechos humanos de manera independiente a su jerarquía, constituyen un canon de interpretación de los derechos constitucionales ${ }^{15}$, la crítica de la doctrina en cuanto a que por vía de los tratados se establecería un mecanismo secundario de reforma constitucional pierde validez. Los tratados no tienen capacidad de reformar la Constitución, sus contenidos contribuyen a delimitar y configurar los derechos: su sentido y alcance, pero no la modifican, ya que los derechos de tratado pasan a formar parte de ella.

Opino que esta es la interpretación que más se adecua a una lectura sistemática de la Constitución. Obviando el debate sobre la jerarquía, el inciso segundo del artículo $5^{\circ}$ puede ser interpretado como un canon hermenéutico, similar al 10.2 de la Constitución española, aunque con diferencias importantes ${ }^{16}$.

\footnotetext{
${ }^{12}$ Irigoln (1996) pp. 299-307.

${ }^{13}$ Sobre la aplicación del DIDH por parte de los tribunales nacionales vid.: Aguilar Cavallo, Gonzalo (2009), Rev. Estudios Constitucionales, pp. 91-136; HenríQuez ViÑAS, Miriam Lorena (2008), Rev. Estudios Constitucionales, pp. 73-119; NúNEZ (2009) pp. 487-529; FERnÁNdeZ (2010), Rev. Estudios Constitucionales, pp. 425-442; ZúNIGA (2007), Rev. Estudios Constitucionales, pp. 525 a 531.

${ }^{14}$ En este sentido: FernándeZ (2003) pp. 485-511.

${ }^{15}$ PeÑA (2008) pp. 205-222. La profesora Peña sostiene que se trata de un "criterio hermenéutico implícito" que se desprende del inciso segundo del artículo $5^{\circ}$ de la Constitución.

${ }^{16}$ En la Constitución española este criterio es obligatorio (artículo 10.2 de la CE).
} 
Esta es nuestra opinión de esta norma. Esta tesis atribuye un contenido útil a la reforma de 1989: no supone el reconocimiento de jerarquía constitucional a los tratados, pero vincula el contenido y alcance de los derechos constitucionales con los derechos contenidos en tratados ratificados y vigentes y en normas del ius cogens, según la jurisprudencia de la Corte Suprema. Este reconocimiento no supone una apertura indiscriminada a todo el Derecho Internacional, sino que se relaciona con los compromisos asumidos en relación con determinados derechos, y es una vía para dar cumplimiento real y oportuno a dichos compromisos.

La polémica sobre la jerarquía de los tratados también va siendo superada paulatinamente por el Tribunal Constitucional, que sin modificar su primer criterio acerca del rango infraconstitucional de los tratados. Desde el año 2006 cuando se modificó su integración y competencias ${ }^{17}$, ha invocado los tratados internacionales de los que Chile es parte bajo las siguientes modalidades ${ }^{18}$ :

i) Para reforzar argumentos: Tribunal Constitucional sentencias, Rol 481, de 4 de julio de 2006; Rol 519, de 5 de junio de 2007; Rol 728 de 3 de julio de 2007; Rol 807, de 4 de octubre de 2007; Rol 576, de 24 de abril de 2007.

ii) Para conformar el contenido de los derechos: los tratados contribuyen a delimitar su titularidad. Tribunal Constitucional Rol 740-07, sentencia de 18 de abril de 2008.

iii) Como parámetro de constitucionalidad: Tribunal Constitucional Rol 786, sentencia de 13 de junio de 2007.

iv) En el reconocimiento constitucional de los derechos esenciales contenidos en tratados ratificados y vigentes. Tribunal Constitucional, sentencias: Rol 740, de 18 de abril de 2008, Rol 1.340 de 29 de noviembre de 2009.

v) Criterios interpretativos del DIDH son invocados para la elaboración del juicio de constitucionalidad: Rol 740-07, sentencia de 18 de abril de 2008.

Dicho esto, la principal crítica que se plantea a las actuaciones del TC en este ámbito, es la disparidad de los criterios que aplica a la hora de introducir referencias al DIDH en sus juicios de constitucionalidad ${ }^{19}$. Esta falta de claridad dificulta la posibilidad de establecer reglas o principios que permitan comprender las razones y la oportunidad para que esta conexión de produzca. Dicho en palabras simples, a veces esta referencia se produce y otras no. Resulta evidente que al interior del tribunal hay posiciones divergentes y no existe, por el momento, un contexto que permita elaborar criterios más claros en esta materia.

${ }^{17}$ PeÑa (2008) pp. 205-222.

${ }^{18}$ Estas categorías son propuestas para el caso español por Fernando Rey: Rey (1989) pp. 3611-3622.

${ }^{19}$ Por ejemplo, Tribunal Constitucional Rol No 728 (2007). 
En la actualidad, el consenso alcanzado en el TC llega hasta promover que los juicios de constitucionalidad elaborados desde el derecho interno, sean reforzados con referencias al Derecho Internacional de los Derechos Humanos, a la doctrina y a la jurisprudencia comparada. Además, en algún caso más reciente, establecida la vinculación entre la dignidad y el derecho a la identidad, el TC ha admitido que este derecho forma parte del catálogo que la Constitución ampara, sin que este derecho esté recogido en la Constitución ${ }^{20}$.

Pero los consensos alcanzados en la definición de la relación Derecho Internacional-Derecho interno, se encuentran con un escollo importante: mientras el Poder Judicial y el Tribunal Constitucional van avanzando hacia una solución compartida, para la mayoría del Poder Legislativo la ausencia de una respuesta definitiva en esta cuestión, opera como excusa para negarse a legislar en algunos ámbitos concretos como el juzgamiento de las violaciones graves a los derechos; como si los tratados internacionales sólo generaran obligaciones en la hipótesis de su jerarquía constitucional, como si el juez no hubiera dado pasos para resolver estas tensiones.

En seguida se analizará el desarrollo que en este sentido han elaborado los jueces y los problemas que se han planteado en sede legislativa sobre esta cuestión.

\section{LA JURISPRUDENCIA DE LOS TRIBUNALES SUPERIORES}

El camino que ha desarrollado la jurisprudencia ha sido largo y sus criterios se han modificado en el tiempo, en este proceso la Ley de Amnistía y la prescripción son los dos obstáculos que los jueces han debido enfrentar durante estos años.

Aunque el deber de prevenir, juzgar y sancionar no tiene una naturaleza jurídica clara, en la jurisprudencia de los tribunales superiores se han identificado algunos elementos que contribuyen a delimitarla y que le vinculan al derecho a la tutela judicial efectiva, que en las violaciones graves a los derechos humanos resulta doblemente reforzada. Es en el sistema europeo e interamericano de protección a los derechos humanos donde se ha construido este criterio.

Siguiendo la doctrina del Tribunal Europeo de Derechos Humanos, el Tribunal Constitucional español ha dicho: "que la tutela judicial efectiva de quien denuncia haber sido víctima de torturas... exige, según el canon reforzado de motivación, una resolución motivada y fundada en Derecho y acorde con la prohibición absoluta de tales conductas, en que se «ha de tener en cuenta la gravedad de la quiebra de esta prohibición y el tipo de actividad judicial necesaria para preservarla dadas su difícil detectabilidad y la especial dependencia respecto de dicha actividad judicial

${ }^{20}$ Tribunal Constitucional Rol No 1.340-09 (2009). 
de la indemnidad de la dignidad de la persona, objeto central de protección de la prohibición. Es de señalar en tal sentido que se trata de una tutela judicial doblemente reforzada que no encuentra parangón en otras demandas de auxilio judicial, pues se pide la tutela judicial frente a la vulneración de un derecho fundamental que constituye un derecho absoluto cuya indemnidad depende esencialmente de dicha tutela judicial»... Del mismo modo, y en relación con lo anterior, también ha señalado en la misma Sentencia que en estos casos «el derecho a la tutela judicial efectiva sólo se satisface si se produce una investigación de lo denunciado que sea a su vez suficiente y efectiva, pues la tutela que se solicita consiste inicialmente en que se indague sobre lo acaecido. Tales suficiencia y efectividad sólo pueden evaluarse con las circunstancias concretas de la denuncia y de lo denunciado, y desde la gravedad de lo denunciado y su previa opacidad, rasgos ambos que afectan al grado de esfuerzo judicial exigido por el art. 24.1 CE»"21.

En cuanto a la jurisprudencia nacional, se pueden distinguir tres etapas en la aplicación del Derecho Internacional de los Derechos Humanos. La primera niega valor a los tratados y aplica preferentemente la legislación nacional; en la segunda, los tribunales superiores matizan su posición e introducen algunas reflexiones sobre límites provenientes de obligaciones contraídas por el Estado en el ámbito del Derecho Internacional. En la tercera y actual etapa, la mayoría de la jurisprudencia considera inaplicables la amnistía y la prescripción, aunque como se ha dicho, todavía persisten ámbitos donde la jurisprudencia es pendular.

\section{IV.1. La creciente aplicación del Derecho Internacional por los jueces nacionales}

En la sentencia del caso Sandoval22, la Corte Suprema rechazó los recursos de casación en la forma y fondo contra la sentencia del Ministro de Fuero que condenó a miembros del ejército y de la DINA y confirmó las penas de reclusión para sus responsables. Los jueces calificaron la desaparición forzada como una infracción grave a los Convenios de Ginebra, por tanto, fuera del ámbito sustantivo y temporal del D.L., porque que se trató de un delito permanente y concluyeron:

a) Las Convenciones de Ginebra son de aplicación preferente;

b) A la luz de la normativa internacional la desaparición forzada de personas es una infracción grave a los Convenios y, en consecuencia, conforme al artículo

\footnotetext{
${ }^{21}$ STC 34/2008. En este caso el Tribunal Constitucional español se refiere a la doctrina del TEDH (Tribunal Europeo de Derechos Humanos) en el caso Kmetty c. Hungría, sentencia de 16 de diciembre de 2003; Martínez Salas y otros c. España. Además, se puede examinar otras sentencias del Tribunal Constitucional español sobre la materia: STC: 52/2008, 123/2008, 224/2007.

${ }^{22}$ Corte Suprema. Juan Contreras Sepúlveda y otro (2004).
} 
148, ha quedado vedada la aplicación de medidas que amparen esos agravios y consigan la impunidad de sus autores;

c) Desde el punto de vista del derecho interno el delito se tipifica como secuestro calificado, es decir, un delito permanente.

En la sentencia, los jueces se valieron a título ilustrativo de: "la Convención Americana sobre Desaparición Forzada de Personas, la doctrina de la Comisión de Derecho Internacional de Naciones Unidas y la resolución que creó el Tribunal Internacional para juzgar los delitos cometidos en la ex Yugoslavia, así como el Estatuto de la Corte Penal"23. Los responsables de la desaparición de Miguel Ángel Sandoval fueron condenados por el delito de secuestro permanente, tipificado en el art. 141 del Código Penal: "De lo anterior fluye claramente que la condena en comento se asentó en el artículo 141 , incisos $1^{\circ}$ y $4^{\circ}$, del Código punitivo, que reprime el delito de secuestro calificado, lo que resulta evidente de la sola lectura del fundamento trigésimo tercero del fallo en revisión, y no en las regulaciones que invoca el impugnante, las cuales sólo dan cuenta de la importancia del delito cometido y como, a través del tiempo, se ha tratado de reforzar aún más la idea del respeto a la libertad individual como un bien jurídico de la mayor importancia, así como el reconocimiento a la vida y dignidad de las personas y de quienes tienen el justo y legítimo derecho de conocer el paradero de los que han sido detenidos"24. En cuanto a la prescripción, los sentenciadores señalaron que el tiempo para su cómputo no empezaba sino una vez que el delito hubiera cesado: "Entonces tampoco cabe aplicar la prescripción de la acción penal alegada, desde el momento que no aparece comprobado en autos que el injusto haya cesado de cometerse, sea por haberse dejado en libertad a la víctima, sea por existir señales positivas y ciertas del sitio donde se encuentran sus restos y de la data de su muerte, en caso de haber ocurrido ésta, por lo que se rechazará el recurso intentado en este sentido"25.

Con esta sentencia se dio inicio a una etapa donde la tesis de la aplicación preferente del DIDH en el ámbito interno se convirtió en criterio dominante, aunque se debe señalar que se han dictado algunos fallos en sentido contrario ${ }^{26}$. Por ejemplo, la sentencia de agosto de 2005 por el homicidio calificado de $\mathrm{Ri}$ cardo Rioseco Montoya y Luis Cotal Álvarez, ocurrida el 5 de octubre de 1973, da buena cuenta de los elementos que los sentenciadores valoraron para considerar que el Decreto Ley No 5 no era un elemento suficiente para acreditar un

\footnotetext{
${ }^{23}$ Corte Suprema. Juan Contreras Sepúlveda y otro (2004). Considerando Decimoctavo.

${ }^{24}$ Corte Suprema. Juan Contreras Sepúlveda y otro (2004). Considerando Decimoctavo.

${ }^{25}$ Corte Suprema. Juan Contreras Sepúlveda y otro (2004). Considerando Trigésimo Nono.

${ }^{26}$ Corte Suprema. Ricardo Rioseco Reyes con Joaquín León Rivera (2005).
} 
conflicto armado en los términos del artículo $3^{\circ}$ de los Convenios: porque no "se ha acreditado en autos que el 12 de septiembre de 1973 existía en Chile la rebelión militarizada capaz de provocar el estado de guerra interno, situación que ni siquiera se mencionó en los considerandos del aludido D.L. No 5, de 1973”. También concluyeron que incluso de ser aplicables las Convenciones, ellas no contienen ningún tipo de prohibición para aplicar otras causales de extinción de la responsabilidad penal.

Asimismo, la Corte de Apelaciones de Santiago ha manifestado un nuevo matiz en el caso por la desaparición forzada de David Urrutia Galaz, ocurrida el 20 de diciembre de 1975, Rol No 14.281-06, de 2007, donde sostuvieron que el D.L. No 5 sólo rigió entre el 12 de septiembre de 1973 y el 11 de septiembre de 1974, y sólo durante ese período puede entenderse que hubo un conflicto armado interno. En cuanto a la prescripción, consideraron que ningún tratado ratificado por Chile con anterioridad a la fecha de los hechos había establecido un límite para su declaración.

Los consensos alcanzados, sin embargo, no alcanzan a resolver todavía dos asuntos: la aplicación de la prescripción gradual y las fluctuantes opiniones en lo que se refiere a la responsabilidad civil y la reparación.

\section{2. Los ámbitos donde subsiste la controversia jurisprudencial}

\section{IV.2.1. Media prescripción}

La invocación de los tratados internacionales, base fundamental para declarar inaplicables la amnistía y la prescripción, han incidido de manera mucho más difusa en el tratamiento de la pena, esto es, la sanción que se impone a los responsables de crímenes de lesa humanidad. En este asunto, los jueces han introducido algunos criterios que el equipo jurídico de $\mathrm{FASIC}^{27}$ calificó como la tesis de la "justicia con clemencia”. Ello implica que se imponen penas que permiten a los condenados acceder al beneficio de la libertad vigilada ${ }^{28}$. Estas condenas han sido consideradas bajas, atendiendo la gravedad del delito, ya que hacen inoperante la garantía de no repetición elaborada por la Corte Interamericana.

En esta materia es importante considerar que en 2007 la Corte Suprema, si bien confirmó el criterio por el cual la prescripción es una medida inaplicable a los crímenes de lesa humanidad, en cambio dio lugar en algunos casos a la aceptación de la atenuante especial de media prescripción que permite rebajar la pena una vez

\footnotetext{
${ }^{27}$ Informe de FASIC. "Balance de Derechos Humanos 2008". Disponible en:http://www.fasic.org/doc/ docs.htm

${ }^{28}$ FeLdens (2005) pp. 80-85.
} 
que ésta ha sido determinada. La Corte consideró que la prohibición contenida en el DI no alcanza la atenuación de la pena, que sólo se referiría al efecto extintivo de la responsabilidad penal. La sentencia de la Corte Suprema Rol No 6.525-06 señala: "Que, en cuanto a la excepción de prescripción de la acción penal invocada por la defensa del encausado, ha de tenerse en cuenta que ésta es improcedente... de acuerdo a las reglas del Derecho Internacional sobre imprescriptibilidad de los crímenes de esta naturaleza... Que respecto a la media prescripción, denominada también prescripción gradual, parcial o incompleta, además de lo razonado por el Juez de primera... cabe considerar, también, para declarar su concurrencia, el carácter de norma de orden público y, por ende, de aplicación obligatoria para los Jueces, que inviste el artículo 103 del Código Penal que la consagra, por lo que en virtud del principio de legalidad que gobierna al derecho punitivo, no se advierte ningún obstáculo constitucional, legal, de tratados internacionales ni de jus cogens para su aplicación, desde que aquellas prescripciones sólo se limitan al efecto extintivo de la responsabilidad criminal. De esta manera, transcurridos que fueron íntegramente los plazos establecidos para la prescripción de la acción penal derivada del ilícito, sin que se la pueda declarar por impedirlo los Convenios de Ginebra, no se divisa inconveniente para mitigar, como atenuante, la responsabilidad penal que afecta al encausado..." 29 .

El problema de la pena, del quantum de la sanción, es un asunto que aborda el Estatuto de la Corte Penal, pero que Chile ha ratificado en junio de 2009, de manera que no se tuvo a la vista al momento de dictar las sentencias. La materia también es tratada en la IV Convención de Ginebra en el artículo 146, cuando señala que las Altas Partes Contratantes se comprometen a tomar medidas legislativas que determinen adecuadas sanciones penales para los responsables de infracciones graves a los convenios.

Según se desprende de las últimas condenas, en criterio de los jueces, una sanción adecuada no supone privación de libertad. Es evidente que la carencia de desarrollo normativo para esta clase de crímenes deja al juez un marco amplio de actuación, sin perjuicio de que el ordenamiento jurídico nacional ya le entrega suficientes herramientas para que, basándose en la gravedad del hecho y los bienes jurídicos en juego, se pueda aplicar sanciones proporcionales. Por otra parte, la Ley

\footnotetext{
${ }^{29}$ Corte Suprema. Estado de Chile; Miriam Luz Ancacura; Pafín; María Ester Hernández Martínez; con Sergio Héctor Rivera Bozzo (2007).

En el mismo sentido: Corte Suprema. Fiscalía Judicial; Maria Angélica Rivera Sánchez; Juan Patudo Rivera Sánchez; Gaby Lucia Rivera Sánchez; Jovina del Carmen Rivera Sánchez; Olga Matilde Rivera Sánchez; Cecilia de las Mercedes Rivera Sánchez; Juan Carlos Rivera Sánchez con Freddy Enrique Ruiz Bunger; Carlos Arturo Madrid Hayden; Álvaro Julio Federico Corbalán Castilla; Sergio Antonio Díaz López (2007).
} 
No 20.357 publicada el 18 de julio de 2009, aunque tipifica y asigna penas a los crímenes de guerra y de lesa humanidad, es posterior a la época de los crímenes de la dictadura chilena; no puede ser directamente aplicada a hechos ocurridos antes de su vigencia, lo que no impide que el juez pueda tenerla a la vista a la hora de analizar los hechos y su gravedad.

\section{IV.2.2. La responsabilidad civil en causas por graves violaciones a los derechos humanos}

La responsabilidad civil, a diferencia de lo que ocurre con la responsabilidad penal, ha sido menos abordada en el Derecho Internacional convencional. El problema se produce cuando el deber de reparación pugna con la amnistía o la prescripción según aplicación de normas civiles.

La complejidad de este asunto y los distintos principios que inspiran a la responsabilidad civil y penal inciden para que la jurisprudencia de los tribunales nacionales sea oscilante.

En esta materia la discusión radica en si acaso la obligación de reparar, al igual que el deber de investigar y sancionar, se extingue por el transcurso del tiempo y si acaso puede ser objeto de amnistía.

En lo que se refiere a la extinción de esta responsabilidad por el transcurso del tiempo, no siempre la jurisprudencia que ha dado aplicabilidad al DIDH concluye la imprescriptibilidad de la responsabilidad extracontractual. Se han encontrado en esta materia tres tesis que se sistematizan a continuación:

A) La tesis de la imprescriptibilidad de la responsabilidad penal y civil en casos de delitos permanentes

En el caso por la desaparición forzada de Manuel Edgardo Cortez Joo, los sentenciadores consideraron que por tratarse de un delito de carácter permanente, el mismo criterio ha de aplicar a la responsabilidad civil. Estimaron que esta acción, como la penal, no había prescrito ni podía aplicarse amnistía ${ }^{30}$ : "Que, respecto de la prescripción opuesta por la defensa de Zapata, Wenderoth y Romo, según lo reseñado en el apartado $59^{\circ}$ que precede, cabe señalar que la acción de indemnización de perjuicios ejercida en este proceso, tiene el plazo de prescripción que contempla el artículo 2332 del Código Civil, esto es, de cuatro años 'contados desde la perpetración del acto’, lo cual obliga al intérprete, al tenor del artículo 20 del citado estatuto, a recurrir al Diccionario de la Lengua Española, según el cual 'perpetrar significa cometer, consumar un delito o culpa grave y, como por su parte, cometer importa en una de sus acepciones: ....acometer (emprender, intentar) y

${ }^{30}$ Corte Suprema. Luisa Faustina Joo con Miguel Krassnoff Martchenko; Luis Manuel Moren Brito; Osvaldo Enrique Romo Mena; Rolf Gonzalo Wenderoth Pozo; Basclay Humberto Zapata Reyes (2007). 
consumar, a su vez, importa llevar a cabo totalmente algo', si incorporamos a este análisis gramatical lo razonado en los apartados $23^{\circ}$ y $24^{\circ}$ del fallo, en cuanto a que el delito de secuestro de que es víctima Manuel Edgardo Cortez Joo es de carácter permanente, no podemos sino concluir que la acción civil deducida en autos no se encuentra prescrita en los términos del artículo 2332 del Código antes citado" ${ }^{31}$. En este caso, los jueces evaluaron el daño en $\$ 20.000 .000$ (veinte millones de pesos) y condenaron a los responsables individuales a resarcir este monto ${ }^{32}$.

B) La tesis que, aplicando el DIDH en materia penal, respecto a la responsabilidad civil aplica reglas de prescripción contenidas en el Código Civil

En el proceso por la responsabilidad civil del Estado por el homicidio de prisioneros de guerra, la Corte suprema ratificó la vigencia y aplicabilidad de las Convenciones de Ginebra en lo que se refiere a la responsabilidad penal ${ }^{33}$, pero respecto a la responsabilidad del Estado, consideró que las limitaciones impuestas por el art.131 de la Convención de Ginebra sobre Tratamiento de Prisioneros de Guerra, no la alcanzaban. Por esta razón procedió a aplicar las normas generales sobre prescripción de la responsabilidad contractual y extracontractual contenidas en el Código Civil, así lo señala la Corte en el siguiente caso: "DECIMOCUARTO: Que la circunstancia que la detención de don Juan Chamorro Arévalo haya dado lugar a la desaparición de la víctima y que esta situación, así como la carencia de informaciones sobre su destino se hayan prolongado en el tiempo, no impide la aplicación en la especie del precepto antes examinado, sin que sea dable hacer el distingo expuesto en el fallo de primera instancia y reiterado en la sentencia recurrida, acerca de la índole compleja del hecho y la proyección posterior de sus efectos, si se tienen presente los términos de dicha disposición legal y que también otras acciones ilícitas pueden causar un daño moral indefinido a los deudos de la víctima, como sucede si provocan el fallecimiento de ésta, sin que por ello dejen de constituir una misma actuación en cuanto se refiere al cómputo del plazo en que prescribe la acción indemnizatoria... Que de lo anterior resulta que la sentencia impugnada cometió el error de derecho invocado en el recurso de autos al dejar de hacer efectiva en este juicio la regla de prescripción del citado artículo 2332 del Código Civil..."34.

\footnotetext{
${ }^{31}$ Ibídem, Corte Suprema (2007).

${ }^{32}$ Un criterio distinto fue sostenido por la misma Corte en: Corte Suprema. Pizani Burdiles, Gladys del Carmen y otra con Fisco de Chile (2003).

${ }^{33}$ Corte Suprema. Julio Artemio Vergara Jofré; Hugo Antonio Vergara Muñoz; Alberto Santander Muñoz con Fisco de Chile (2004), Considerando Séptimo. En el mismo sentido: Corte Suprema. Domic Bezic y otros con Fisco (2002).

${ }^{34}$ Corte Suprema. Pizani Burdiles, Gladys del Carmen y otra con Fisco de Chile (2003). Considerando Octavo.
} 
C) La tesis de la incompatibilidad de la reparación del daño moral con las prestaciones establecidas en la Ley No 19.123

Las medidas de reparación impulsadas por el Ejecutivo en la Ley No 19.123 y modificaciones de la Ley No 19.980, han sido consideradas en algunos casos al momento de analizar la responsabilidad patrimonial del Estado. En un caso por indemnización del daño moral sufrido por secuestro y posterior desaparición, la Corte Suprema señaló: "es un principio general de derecho el que un daño que ya ha sido reparado no da lugar a indemnización, por lo que quienes impetraron, y recibieron... beneficios de dicha ley, no pueden demandar una nueva indemnización por los mismos hechos. En efecto, el aceptar otras indemnizaciones por el daño moral por parte del Estado, además de los beneficios reparatorios concedidos en aquella ley y percibidos por el beneficiario, importa una doble indemnización del mismo perjuicio... Que lo razonado en los considerandos que preceden conduce necesariamente a concluir que existe incompatibilidad entre la acción indemnizatoria del daño moral invocada por los actores y la pensión de reparación y demás beneficios de la Ley No 19.123..." 35 .

Un criterio similar sostuvo la Corte IDH en el caso Almonacid Arellano vs. Chile. En este caso, la Corte consideró que el Estado había dado cumplimiento a este deber a través de los distintos beneficios que el Estado había concedido en éste y otros casos análogos ${ }^{36}$.

A la vista de las sentencias analizadas, para los jueces si bien la limitación de la autoexoneración que las Convenciones de Ginebra imponen al Estado comprende la amnistía y la prescripción, el mismo criterio no se aplicaría a la responsabilidad civil.

Existe abundante y reiterada jurisprudencia de la Corte IDH que sostiene que el deber de reparar graves violaciones a los derechos humanos comprende naturalmente el deber de reparar el daño, que tampoco podrá estar sujeto a limitaciones, tal y como ocurre con la responsabilidad penal ${ }^{37}$.

En relación a esta materia, durante el año 2008 se dictaron sentencias tanto a favor, como en contra de la inaplicabilidad de la prescripción de la acción civil, quizás lo más destacado de este año es que mientras en algunos casos se ha decla-

${ }^{35}$ Corte Suprema. Hilda Elena Espinoza Figueroa; Esteban Rodolfo Rioseco Espinoza; con Fisco de Chile (2006).

${ }^{36}$ Caso Almonacid Arellano vs. Chile. Serie C No 154. Sentencia de 26 de septiembre de 2006. Párrafos 138 y 161.

${ }^{37}$ Corte IDH, Caso Almonacid Arellano vs. Chile, Considerando 136. 
rado la prescripción, en otros se ha reconocido la imprescriptibilidad del derecho a reparación.

Los diversos criterios aplicados implica que en algunos casos se reconoce el derecho a la indemnización y en otros no, y este es un resultado difícilmente aceptable y comprensible para las víctimas. Sobre esta polémica, considero que ni la responsabilidad penal ni la civil prescriben, precisamente, por la intensidad de la lesión.

En cuanto a las reparaciones que ya se han concedido por ley, me sumo a los criterios desarrollados por la Corte IDH en el caso Almonacid Arellano vs. Chile (aunque debe aclararse que la Corte entendió que tenía competencia para pronunciarse sobre la denegación de justicia y no sobre la violación del derecho a la vida). En este caso, la Corte consideró que el Estado había dado cumplimiento al deber de reparación a través de los distintos beneficios que el Estado había concedido en éste y otros casos análogos: "En el capítulo de Hechos Probados, este Tribunal tuvo como demostrado que Chile, a partir del retorno a la democracia, ha llevado adelante una política de reparaciones por las violaciones perpetradas durante el período de dictadura militar. Esta política ha beneficiado a las víctimas sobrevivientes y a los familiares de las víctimas fallecidas o desaparecidas, y ha buscado la reconciliación nacional. La Corte celebra los pasos dados por el Estado y resalta el trabajo de la Comisión Nacional de Verdad y Reconciliación, de la Corporación Nacional de Reparación y Reconciliación y de la Comisión Nacional sobre Prisión Política y Tortura... Asimismo, es un hecho no controvertido que los familiares del señor Almonacid Arellano se beneficiaron de esta política de reparación estatal... la Corte valora positivamente la política de reparación de violaciones a derechos humanos adelantada por el Estado... Teniendo en cuenta todo lo anterior, el Tribunal considera no ordenar el pago de una compensación económica por concepto de daño inmaterial, debido a que estima, como lo ha hecho en otros casos, que esta sentencia constituye per se una forma de reparación, y que las medidas que se detallan en los párrafos 145 a 157 de esta Sentencia constituyen una debida reparación en los términos del artículo 63.1 de la Convención Americana"38.

Conforme lo señalado por la Corte, sería pertinente que en los casos donde se persigue la reparación del daño, los tribunales nacionales analizaran caso a caso, las reparaciones que se han otorgado por vía legislativa y que dichas reparaciones fueran consideradas a la hora de establecer las reparaciones en el proceso.

${ }^{38}$ Corte IDH, Caso Almonacid Arellano vs. Chile, párrafos 138 y 161. 


\section{PRINCIPIO DE LEGALIDAD PENAL Y PROBLEMAS DOGMÁTICOS}

El desarrollo jurisprudencial que se ha examinado no ha estado exento de polémica; los mismos debates se han producido en todas las jurisdicciones que se han visto enfrentadas al juzgamiento de violaciones graves a los derechos humanos ocurridas en el pasado ${ }^{39}$.

El reconocimiento de la eficacia de los tratados en el orden interno incide en la ampliación del contenido y alcance de la tutela judicial y estos nuevos contenidos pueden acarrear tensiones en su relación con otros derechos y principios. Pero no toda aplicación del DIDH y DPI plantea problemas, para su mejor comprensión es necesario delimitar esta cuestión. No existen dificultades cuando existe desarrollo normativo de los derechos y obligaciones contenidos en tratados internacionales y estos compromisos afectan a hechos futuros. Dicho esto, cuando la aplicación de las obligaciones contenidas en el DI afecta hechos o situaciones ocurridas antes de su desarrollo normativo, se plantearán tensiones respecto al principio de legalidad penal.

En este punto cabe además otra reflexión. Si la fuente del DI es un principio del ius cogens, y esta norma es invocada como principio imperativo y no como tratado, se producirá un problema adicional para determinar la obligatoriedad de esas normas en el derecho interno. Así ocurre con la imprescriptibilidad de los crímenes de guerra y de lesa humanidad.

Las respuestas elaboradas desde la jurisdicción constitucional latinoamericana se han decantado por favorecer la aplicación de las normas de tratado, negando que su aplicación afecte el principio de legalidad. Esta interpretación ha provocado críticas de parte de la doctrina de los penalistas y algunos sectores de la jurisprudencia. Los debates se han centrado en la aplicación de los tratados y el respeto al principio de legalidad (lex praevia, scripta, certa, stricta) que en la Constitución chilena es reconocido en el art. 19 No 3 incisos $7^{\circ}$ y $8^{\circ 40}$.

\footnotetext{
${ }^{39}$ No puedo dejar de referirme al caso de España y la reciente resolución de la Sala Penal del Tribunal Supremo español que ha ordenado apertura de juicio oral contra el Juez Baltasar Garzón por delito de prevaricación, al haber dado trámite a la investigación por crímenes de guerra y de lesa humanidad ocurridos durante la dictadura del general Franco. En el caso español no se desconocen las consecuencias jurídicas de los delitos contra la humanidad, sino su vigencia en la época de la guerra civil. El Ministerio Fiscal señaló que los crímenes contra la humanidad sólo se introducen en España en 2004 en el artículo 137 bis, ahora artículos 607 y 607 bis, pero el juez sostiene que se trata de una figura preexistente, obligatoria independientemente de su regulación legislativa, tal como lo había reconocido el Ministerio Fiscal en otras actuaciones. Audiencia Nacional de España. Auto del Juzgado de Instrucción No 553/2008 E, de 18 de noviembre de 2008.

${ }^{40}$ Constitución de Chile, art. 19 № 3, incisos 70 y $8^{\circ}$ : "Ningún delito se castigará con otra pena que la que señale una ley promulgada con anterioridad a su perpetración, a menos que una nueva ley favorezca al afectado. Ninguna ley podrá establecer penas sin que la conducta que se sanciona esté expresamente descrita en ella".
} 
Asimismo, en el caso de la jurisprudencia de los tribunales superiores chilenos, en algunos casos se ha reconocido jerarquía constitucional para los tratados internacionales sobre derechos humanos ${ }^{41}$. A nuestro juicio, esta conclusión es planteada con el objeto de reforzar los argumentos que impiden aplicar la amnistía y la prescripción a violaciones graves a los derechos humanos, dado que esta conclusión resolvería de manera definitiva las tensiones entre el deber de prevenir, juzgar y sancionar con el principio de legalidad a que hemos hecho referencia. En efecto, este argumento resuelve las tensiones por la vía de la preeminencia y no por la vía de la armonización y delimitación de los derechos en juego. En seguida vamos a intentar desarrollar algunos criterios que resuelven estas tensiones por la vía de la interpretación y delimitación del sentido y alcance de los derechos en juego.

\section{V.1. Principio de legalidad y leyes de amnistía}

La inaplicabilidad de las leyes de amnistía y el indulto en casos por graves violaciones a los derechos humanos, tiene dos respuestas posibles y no excluyentes en la jurisprudencia: por un lado, el origen de las leyes de amnistía; por otro, el respeto a las obligaciones emanadas de tratados que, en la época en que se dictaron las amnistías, ya habían sido ratificados y se encontraban vigentes.

En cuanto al origen de las leyes de amnistía, un antecedente común a esta clase de normas es el contexto jurídico y político en el que han sido dictadas. En el caso chileno, cuando se dictó el D.L. de Amnistía, se había suprimido la división de poderes y estaban suspendidas las garantías de la Constitución de 1925. Esta clase de normas son las llamadas autoamnistías o amnistías al revés y como señalaba el profesor Juan Bustos, "Disposiciones como éstas no son fruto de un acto de indulgencia, que enaltece a quien lo cumple, ni procuran llevar sosiego a la comunidad, sino por el contrario constituyen una burda vulneración del principio de igualdad ante la ley y marca deshonrosa de regímenes tiránicos como el vivido

\footnotetext{
${ }^{41}$ Por ejemplo: Corte Suprema. Juan Contreras Sepúlveda y otro (2004) Considerando Trigésimo quinto:"Que, en consecuencia, el Estado de Chile se impuso, al suscribir y ratificar los citados Convenios, la obligación de garantizar la seguridad de las personas que pudieren tener participación en conflictos armados dentro de su territorio, especialmente si fueren detenidas, quedando vedadas las medidas tendientes a amparar los agravios cometidos contra personas determinadas o lograr la impunidad de sus autores, teniendo especialmente presente que los acuerdos internacionales deben cumplirse de buena fe. $Y$ en cuanto el Pacto persigue garantizar los derechos esenciales que nacen de la naturaleza humana, tiene aplicación preeminente, puesto que esta Corte Suprema en reiteradas sentencias ha reconocido que la soberanía interna del Estado de Chile reconoce su límite en los derechos que emanan de la naturaleza humana; valores que son superiores a toda norma que puedan disponer las autoridades del Estado, incluido el propio Poder Constituyente, lo que impide sean desconocidos".
} 
en Chile. Estas amnistías al revés tienen sólo la forma pero no su contenido jurídico, ni siquiera como manifestación jurídica vinculante, al emanar de decretos leyes de regímenes de facto" ${ }^{42}$.

El D.L. No 2.191, dictado durante el régimen de Pinochet, corresponde a la noción de la autoamnistía. Su falta de validez ha sido defendida por la Corte IDH, cuando ha dicho que esas leyes "carecen de efectos jurídicos y no pueden seguir presentando un obstáculo para la investigación de los hechos que constituyen este caso ni para la identificación y el castigo de los responsables..." ${ }^{43}$. Este es el argumento que ha retomado la jurisdicción argentina, pero no el camino que ha seguido el juez, ni el legislador chileno en el último proyecto de ley que se discute en el Congreso Nacional.

Otra vía para fundamentar la ineficacia de las leyes de amnistía respecto a violaciones graves -que se ha extendido a la prohibición del indulto en la jurisprudencia argentina ${ }^{44}$-, se encuentra en la preexistencia de obligaciones contraídas por el Estado desde la ratificación de los tratados, que impiden su aplicación. Este es el criterio seguido por la jurisprudencia chilena cuando señala que el Estado había adquirido previamente el compromiso de no exonerar ni autoexonerarse de la responsabilidad por la comisión de violaciones graves y que había limitado las facultades de sus poderes públicos para dictarlas.

En nuestra opinión, no obstante reconocer la ilegitimidad del mencionado decreto ley, también es posible defender su inaplicabilidad a las violaciones graves a los derechos humanos por vía de su interpretación. Es decir, entendiendo que este decreto no pudo alcanzar a estas violaciones, porque el Estado al ratificar las Convenciones ya se había comprometido a no exonerar ni autoexonerarse de su investigación y sanción.

Juan Bustos, como académico y parlamentario, se sumó a la tesis de la aprobación de una ley interpretativa para delimitar los delitos que podrían ser amnistiados por vía del D.L., norma que debía dejar fuera de su alcance las violaciones más graves a los derechos humanos. En cuanto a la crítica de Alex Van Weezel, en cuanto a que una ley interpretativa afectaría el principio nulla poena y de favorabilidad ${ }^{45}$, Juan Bustos señaló que las leyes interpretativas debían ser incorporadas a la ley que interpretan y, por tanto, no afectan el contenido del derecho, ya que no hacen

\footnotetext{
42 Bustos, Juan (2007) p. 11.

${ }^{43}$ Caso Barrios Altos Vs. Perú. Serie C No 75. Sentencia de 14 de marzo de 2001. Párrafo 44.

${ }^{44}$ Incidente de inconstitucionalidad de los indultos dictados por el decreto 2741/1990 del Poder Ejecutivo Nacional. Cámara Nacional de Apelaciones en lo Criminal y Correccional Federal en pleno (2007).

${ }^{45}$ Van Weezel (2007) pp.14-30.
} 
más que determinar mayor certeza sus ámbitos de protección. Para Bustos, una ley interpretativa que incorpore explícitamente estas limitaciones es coherente con los criterios sostenidos por los jueces: "Al respecto hay que destacar que ya nuestros tribunales de justicia tanto inferiores como superiores han dictado sentencias interpretando para el caso concreto el sentido que han de tener las menciones a la amnistía y la prescripción establecidas en el artículo 93 del Código Penal, en cuanto ha de entenderse que no a los delitos contra la Humanidad. Luego es la hora que el poder legislativo establezca de modo general la correcta interpretación de estos términos, conforme a lo ya señalado por los tribunales". Bustos, Juan. "Inadmisibilidad de Autoamnistías..."46.

\section{V.2. Principio de legalidad e imprescriptibilidad de crímenes de guerra y lesa humanidad}

Cuando los jueces califican los hechos constitutivos de violaciones graves como crimen de lesa humanidad, una de las consecuencias de esta calificación es que ellos se consideran imprescriptibles ${ }^{47}$. El problema se plantea respecto a si esta importación vulnera el principio de legalidad cuando no existe desarrollo legal de esta condición y la imprescriptibilidad se deriva directamente de una norma del ius cogens internacional ${ }^{48}$. El debate es relevante y de gran interés, aunque en este trabajo no se profundizará sobre sus contenidos, en seguida se presentará una reseña de los principales argumentos que se han expuesto en esta materia ${ }^{49}$.

Para resolver la tensión que la aplicación del Derecho Penal Internacional ha generado respecto al principio de legalidad, Xavier Fernández Pons distingue tres respuestas elaboradas por la jurisprudencia internacional: “a) la negación de la vigencia del principio nullum crimen sine lege en la incriminación internacional del individuo; b) la afirmación de tal vigencia, justificando su vulneración mediante una ponderación de los diversos valores en presencia, y c) la adaptación del principio a las peculiares formas de creación de las normas internacionales, excluyendo el carácter retroactivo de las 'nuevas' incriminaciones y considerándolas como declarativas de un Derecho preexistente" ${ }^{50}$. Fernández Pons añade

\footnotetext{
${ }^{46}$ Bustos (2007) p. 18.

${ }^{47}$ En la jurisprudencia comparada la calificación de un delito conforme al DPI o DIDH, como un crimen de guerra o de lesa humanidad, supone también que los delitos se consideran imprescriptibles e inamnistiables; se activa el principio de jurisdicción universal y la no procedencia de ciertas inmunidades.

${ }^{48}$ En Chile, Antonio Bascuñán Rodríguez cuestiona el creciente desarrollo del deber de punición en el ámbito internacional. BASCUÑÁN (2008).

${ }^{49}$ Vid en el caso de Argentina: Parenti (2008), y Ambos, et al. (2008) p. 21.

${ }^{50}$ Fernández Pons (2002) p. 3.
} 
que la última alternativa ha sido la solución preferida por la jurisprudencia, que también ha sido recogida a nivel convencional en el artículo 15.2 del PIDCP y en el Convenio Europeo para la Protección de los Derechos y de las Libertades Fundamentales ${ }^{51}$. La jurisprudencia constitucional latinoamericana ha trabajado sobre las dos últimas opciones, aunque se ha decantado por la tercera.

Los jueces chilenos han evitado referirse a la ponderación de derechos. Han optado por considerar que no se afecta el principio de legalidad, pero sin referirse a su flexibilización ${ }^{52}$. Han dicho que con la declaración de imprescriptibilidad en el proceso, el principio de legalidad no ha sido afectado porque que la norma era obligatoria para el Estado chileno independientemente de su voluntad y vigente a la época de los hechos. Dicho esto, también los jueces valoran la gravedad de los delitos, aunque hasta ahora no se han encontrado sentencias donde opten claramente por ponderar la vigencia del principio de legalidad.

La doble subsunción ha sido la técnica jurídica que los jueces del entorno latinoamericano han utilizado a la hora de abordar la extinción de la acción penal para la persecución de violaciones graves a los derechos humanos. La mayoría de la jurisprudencia se inclina a sostener la vigencia del principio de legalidad en estos casos, pues considera que la norma contenida en la Convención de 1968 era anterior a los hechos. Según esta regla, para la determinación del tipo y la pena se aplica el derecho interno, pero en lo que se refiere a su perseguibilidad (contenidos procesales del principio de legalidad) es posible aplicar normas del ius cogens internacional -según la jurisprudencia latinoamericana-, ni tampoco se aplica el principio de irretroactividad de la ley penal, según la doctrina alemana para el caso de los centinelas del muro de Berlín. A esta materia se refiere Jescheck, cuando señala: "En el actual Derecho, la prohibición de retroactividad no rige para los preceptos procesales y, por tanto, tampoco es aplicable a los presupuestos del proceso..."; en cuanto a la prescripción, Jescheck afirma que la jurisprudencia no aplica la prohibición de retroactividad a los plazos de prescripción ${ }^{53}$.

\footnotetext{
${ }^{51} 15.2$ del PIDCP: "nada se opondrá al juicio o a la condena de una persona por actos u omisiones que, en el momento de cometerse, fueran delictivos según los principios generales del derecho reconocidos por la comunidad internacional"; Convenio Europeo para la Protección de los Derechos y de las Libertades Fundamentales, artículo 70: "Nadie podrá ser condenado por una acción o una omisión que, en el momento en que haya sido cometida, no constituya una infracción según el derecho nacional o internacional. Igualmente no podrá ser impuesta una pena más grave que la aplicable en el momento en que la infracción haya sido cometida. 2. El presente artículo no impedirá el juicio y el castigo de una persona culpable de una acción o de una omisión que, en el momento de su comisión, constituía delito según los principios generales del derecho reconocidos por las naciones civilizadas".

${ }^{52}$ Corte Suprema. Paulino Rivas y otros (2006) Considerando 25.

53 JESCHECK (1981) p. 186.
} 
En la configuración del principio de legalidad, si se acepta la regla de la imprescriptibilidad sin desarrollo normativo, entonces este principio no puede ser entendido en términos estrictos y sin que se introduzcan las distinciones analizadas. Evidentemente, el reconocimiento de esta condición altera la manera de comprender el principio de legalidad, si al menos en parte su contenido se construye a la luz del ius cogens. Esta es la tendencia que se verifica para el tratamiento de esta clase de crímenes, tanto en la jurisprudencia nacional ${ }^{54}$ como en la internacional.

Dicho lo anterior, buena parte de los problemas que se han identificado, no existirían si ese desarrollo normativo se hubiera concretado, de allí la necesidad de promover que junto a la ratificación de los tratados se produzcan los ajustes legislativos necesarios para dar cumplimiento a los compromisos que se asumen.

\section{Eficacia de los derechos reconocidos en tratados: las (no) actuaciones del legislador}

Los problemas analizados, especialmente el respeto al principio de legalidad penal, también han sido invocados en sede legislativa para justificar las omisiones del legislador en este ámbito; es su efecto respecto a los hechos del pasado y no su regulación hacia el futuro, el argumento para que hasta la fecha no exista desarrollo normativo de la prohibición. Existe un marco político e institucional relevante para analizar las opiniones del legislador en este ámbito.

El Congreso chileno fue cerrado por orden de la Junta Militar entre 1973 y 1989. Su actual composición y atribuciones han sido establecidas en la Constitución de 1980, que no ha sido el resultado de un ejercicio democrático. La Constitución del 80 introdujo dos instituciones para la designación de los legisladores: los senadores vitalicios y los senadores designados. Sólo hasta 2006, cuando entró en vigencia la reforma constitucional promovida por el Presidente Ricardo Lagos, ambas instituciones fueron eliminadas, de hecho, entre los parlamentarios designados el propio Augusto Pinochet asumió como senador entre 1998 y 2002.

Asimismo, el sistema electoral (binominal) para optar al cargo de Senador o Diputado, fue introducido por la Junta Militar mediante Ley Orgánica Constitucional No 18.700 de 1988 y hasta ahora no ha sido reformado. Este sistema se ha traducido en que desde 1990 han tenido representación parlamentaria casi

\footnotetext{
${ }^{54}$ Reconocen estar ante crímenes de guerra o de lesa humanidad, entre otras, las siguientes sentencias: Corte de Apelaciones de Santiago. Eduvina Bedi Ríos Véjar con Augusto Pinochet Ugarte; Sergio Arellano Stark; Odlanier Mena Salinas; Luis Guillermo Carrera Bravo; René Iván Bravo Llanos (2007); Corte de Apelaciones de Santiago. Ernesto Yoliztly Lejderman Avalos con Fernando Guillermo Santiago Polanco Gallardo y otros(2007); Corte de Apelaciones de Santiago. Hirma Villagra Castro con Juan Manuel Guillermo Contreras Sepúlveda; Marcelo Luis Manuel Morel Brito (2008); Corte Suprema. Estado de Chile; Miriam Luz Ancacura; Pafián; María Ester Hernández Martínez; con Sergio Héctor Rivera Bozzo (2007).
} 
exclusivamente los representantes de dos conglomerados: la Concertación de Partidos por la Democracia y la Alianza por Chile, excluyendo la representación política para sectores políticos ajenos a las dos coaliciones.

La regulación que la Constitución de 1980 ha contemplado para el funcionamiento y elección del Congreso Nacional ha incidido para que el Derecho Internacional, en las vertientes que se han analizado, haya encontrado en el legislador la mayor oposición. Esta resistencia no sólo se expresa en la falta de consensos para legislar sobre amnistía y la prescripción, también ha quedado de manifiesto a la hora de ratificar nuevos tratados internacionales en materia de derechos humanos, especialmente aquellos que reconocen el principio de jurisdicción universal o la competencia de órganos no jurisdiccionales para conocer sobre violaciones a los derechos humanos, cuya aprobación ha sido de larga y accidentada tramitación.

En este ámbito, por ejemplo, la Convención Interamericana sobre Desaparición Forzada de Personas aunque fue aprobada en el Congreso, posteriormente un grupo de senadores presentó un requerimiento por inconstitucionalidad que fue acogido por defectos de forma y sólo recientemente ha sido aprobada por el Congreso ${ }^{55}$. Tampoco ha progresado la aprobación de la Convención sobre Imprescriptibilidad de los Crímenes de Guerra y de Lesa Humanidad, pendiente desde 1994.

De la misma manera, cuando se discutió la aprobación del Estatuto de Roma que crea la Corte Penal Internacional, el mismo grupo parlamentario que recurrió la Convención sobre Desaparición Forzada, planteó la inconstitucionalidad del Estatuto $^{56}$. En este punto corresponde advertir que en 2009 el legislador finalmente dio su aprobación a la reforma constitucional que permite la ratificación del Estatuto, que se concretó el 30 de junio de 2009. Luego de largas negociaciones el texto aprobado introduce una disposición transitoria que autoriza al Ejecutivo para su ratificación, y señala expresamente que esta jurisdicción sólo procede respecto a hechos cuyo principio de ejecución sea posterior a su entrada en vigencia ${ }^{57}$.

\footnotetext{
${ }^{55}$ Sentencia del Tribunal Constitucional Rol No 383, sobre inconstitucionalidad del proyecto de acuerdo que aprueba la Convención Interamericana sobre Desaparición Forzada (2003): "Consecuentemente, sostienen que, al otorgarse a un tribunal extranjero atribuciones para conocer de delitos ocurridos dentro del territorio de la República, se está reconociendo potestad jurisdiccional a una autoridad no establecida por la Carta Fundamental, lo que constituye una violación de dicho precepto constitucional".

${ }^{56}$ Vid.: opinión del Senador Sergio Fernández. Informe de la Comisión de Constitución, Legislación, Justicia y Reglamento del Senado, a propósito de la discusión de la reforma constitucional para aceptación de la jurisdicción de la Corte Penal Internacional, Boletines Nos. 2.912-07 y 3.491-07.

${ }^{57}$ Proyecto de Reforma Constitucional: Artículo único. Publicada en el Diario Oficial el 30.05.09.
} 
En el análisis de las actuaciones del legislador chileno, a la luz de la teoría de los derechos fundamentales, se pone en evidencia la resistencia del legislador a reconocer la fuerza normativa de las obligaciones que provienen del Derecho Internacional, y respecto a las cuales, buena parte de los legisladores actúa como si se tratara de una materia sobre la que puede decidir con autonomía. En los hechos, el legislador no parece someterse a los compromisos que se asumen en el ámbito internacional, ni limita sus actuaciones conforme a los compromisos adquiridos. En este sentido, Alejandro Saiz Arnaiz reconoce: "En el momento presente no puede afirmarse sic et simpliciter que la limitación de los poderes del Estado traiga causa únicamente de las previsiones del Derecho interno. Del mismo modo, y en relación con la anterior afirmación, tampoco es posible definir la garantía y reconocimiento de los derechos a partir de fuentes puramente nacionales" 58 .

Esta situación tiene otros matices a partir de septiembre de 2006, cuando la Corte IDH dictó la sentencia condenatoria contra el Estado chileno en el caso Almonacid Arellano vs. Chile, a partir de la cual el desarrollo legislativo de la prohibición adquirió carácter imperativo.

\section{VI.1. El surgimiento de una obligación positiva: la sentencia condenatoria de la Corte IDH en el Caso Almonacid Arellano vs. Chile}

El caso que trasladó el debate al sistema interamericano de protección, fue el caso Almonacid Arellano vs. Chile de 2006. En este caso, la Corte dispuso que conforme al desarrollo del derecho de gentes, cuando un Estado ha ratificado un convenio internacional debe introducir en su derecho interno las modificaciones necesarias para cumplir ese convenio y que el Estado estaba obligado a adaptar su derecho a lo establecido en la $\mathrm{CADH}$ : "Esta Corte ha afirmado en varias oportunidades que '[en] el derecho de gentes, una norma consuetudinaria prescribe que un Estado que ha celebrado un convenio internacional, debe introducir en su derecho interno las modificaciones necesarias para asegurar la ejecución de las obligaciones asumidas. Esta norma aparece como válida universalmente y ha sido calificada por la jurisprudencia como un principio evidente...En este orden de ideas, la Convención Americana establece la obligación de cada Estado Parte de adecuar su derecho interno a las disposiciones de dicha Convención, para garantizar los derechos en ella consagrados..." ${ }^{59}$.

\footnotetext{
${ }^{58}$ SAIZ (2006) p. 43.

${ }^{59}$ Corte IDH. Caso Almonacid Arellano vs. Chile. Excepciones Preliminares, Fondo, Reparaciones y Costas. Sentencia de 26 de septiembre de 2006. Serie C No 154.
} 
Para la Corte, esa adecuación implica entre otras obligaciones: “i) la supresión de las normas y prácticas de cualquier naturaleza que entrañen violación a las garantías previstas en la Convención, y ii) la expedición de normas y el desarrollo de prácticas conducentes a la efectiva observancia de dichas garantías"60.

En cuanto al juez, la Corte consideró que de manera independiente a la actividad del legislador, éste continúa obligado a no aplicar normas que se opongan a la CADH: "La descrita obligación legislativa del artículo 2 de la Convención tiene también la finalidad de facilitar la función del Poder Judicial de tal forma que el aplicador de la ley tenga una opción clara de cómo resolver un caso particular. Sin embargo, cuando el Legislativo falla en su tarea de suprimir y/o no adoptar leyes contrarias a la Convención Americana, el Judicial permanece vinculado al deber de garantía establecido en el artículo 1.1 de la misma y, consecuentemente, debe abstenerse de aplicar cualquier normativa contraria a ella..."61.

La Corte IDH concluyó que el D.L. de Autoamnistía es incompatible con la $\mathrm{CADH}$ y carece de efectos jurídicos, y ordenó al Estado a tomar las medidas necesarias para que no siga siendo un obstáculo en la investigación de violaciones graves a los derechos humanos: "la Corte dispone que, al pretender amnistiar a los responsables de delitos de lesa humanidad, el Decreto Ley No 2.191 es incompatible con la Convención Americana y, por tanto, carece de efectos jurídicos; en consecuencia, el Estado debe: i) asegurar que no siga representando un obstáculo para la investigación de la ejecución extrajudicial del señor Almonacid Arellano y para la identificación y, en su caso, sanción de los responsables, y ii) asegurar que el Decreto Ley No 2.191 no siga representando un obstáculo para la investigación, juzgamiento y, en su caso, sanción de los responsables de otras violaciones similares acontecidas en Chile..." 62 . La prohibición se estableció en términos que el Estado no podía volver a excusarse del cumplimiento de este deber por aplicación de la amnistía, la prescripción, la irretroactividad de la ley penal, ni tampoco podía invocar el principio ne bis in idem y cualquier excluyente similar de responsabilidad.

Pese al tenor de la sentencia, en lo que se refiere al legislador, a pesar de algunos ensayos, hasta ahora no ha sido cumplida.

En la actualidad, de todos los proyectos destinados a limitar la procedencia de la amnistía, prescripción e indulto, el principal proyecto en discusión es el que interpreta el artículo 93 del Código Penal. Es el más comprensivo (incluye la

${ }^{60}$ Ibíd.

${ }^{61}$ Ibíd.

${ }^{62}$ Ibíd. 
amnistía, la prescripción y el indulto) y cuenta con mayor respaldo en la doctrina, pero a pesar de los avances del proyecto en la Cámara de Diputados, desde julio de 2008 su tramitación está en suspenso en el Senado que ha objetado su aprobación por defectos de forma, como se examinará en seguida.

\section{VI.2. Los ensayos legislativos}

Según la información que registra la página web del Congreso chileno, desde 1992 y hasta 2008, han ingresado a trámite a lo menos 17 proyectos de ley que se vinculan a distintas temáticas sobre derechos humanos: esclarecimiento histórico; reforma constitucional para favorecer la educación en derechos humanos; limitaciones a las leyes de amnistía, a la institución de la prescripción y concesión del indulto en caso de graves violaciones a los derechos humanos ${ }^{63}$; aprobación de la Convención sobre Imprescriptibilidad de los Crímenes de Guerra y de Lesa Humanidad. De todos ellos, pocos han llegado a convertirse en ley ${ }^{64}$.

${ }^{63}$ Boletín 1657, 19 de julio de 1995, Dicta normas para la aplicación de la amnistía, restringe procedencia al sobreseimiento temporal, establece procedimiento judicial para determinar el paradero de las personas detenidas y desaparecidas o de sus restos. Archivado 20.06.2001. Moción presentada por los senadores: Sergio Diez, Hernán Larraín, Carlos Letelier, Miguel Otero y Sebastián Piñera.

${ }^{64}$ Senado de la República, proyectos de leyes: Boletín 656-07, 7 de abril de 1992, Interpreta Decreto Ley No 2.191 de 1978 sobre amnistía. Archivado 09.05.2001; Boletín 1681-07, 22 de agosto de 1995, Proyecto de ley que dicta normas para contribuir al esclarecimiento de la verdad en torno al destino de los detenidos desaparecidos y otros casos sobre derechos humanos. Archivado 09.07.1997; Boletín 1718-07, de 11 de octubre de 1995, Interpreta artículos $1^{\circ}$ y $3^{\circ}$ del D.L. No 2.191 sobre amnistía, tratándose de delitos que el Derecho Internacional califica de lesa humanidad. Archivado 05.07.2000; Boletín 1265-10, de 6 de julio de 1994, Aprueba la Convención sobre Imprescriptibilidad de los Crímenes de Guerra y de Lesa Humanidad, en primer trámite constitucional desde 04.03.2008; Boletín 3317-07, de 26 de agosto de 2003, Proyecto de ley que tipifica delito de desaparición forzada de personas. Archivado 13.03.2006; Boletín 3345-07 de 9 de septiembre de 2003, Interpreta y adecua la legislación penal chilena a los tratados internacionales en materia de derechos humanos, refundido con Bol. 3595. Etapa: discusión general; Boletín 3959, de 30 de agosto de 2005. Interpreta artículo 93 de Código Penal en materia de prescripción de la acción penal en caso de delitos especialmente sancionados por el Derecho Internacional. Etapa: discusión general; Boletín 3980-07 de 7 de septiembre de 2005, Modifica Ley No 18.05 que fija normas sobre indultos particulares adecuando sus normas a los tratados internacionales ratificados por Chile y que se encuentren vigentes, con el fin de que no se pueda conceder indulto a las personas condenadas por crímenes de lesa humanidad. Etapa: primer informe de la Comisión de Constitución; Boletín 4162-07, de 21 de abril de 2006. Proyecto de ley que declara nulidad del D.L. No 2.191 de 1978. Etapa: Primer informe de la Comisión de Derechos Humanos; Boletín 5918-07 de 11 de junio de 2008, Interpreta artículo 93 del Código Penal, excluyendo de la extinción de la responsabilidad penal por amnistía, indulto o prescripción a los crímenes y simples delitos que constituyen genocidio, crímenes de lesa humanidad y de guerra, contenidos en los tratados internacionales ratificados por Chile y que se encuentren vigentes. Etapa: Primer informe de la Comisión de Constitución; Boletín 4768-07 de 2 de enero de 2007, Establece Jerarquía Constitucional de los tratados internacionales sobre derechos humanos ratificados por Chile. Etapa: informe de la Comisión de Constitución; Boletín 4727-07 de 13 de diciembre de 2006, Impide la dictación del sobreseimiento definitivo en caso de muerte del imputado por delitos que no pueden prescribir o amnistiarse. Etapa: primer informe de la Comisión de Constitución; Boletín 
Según los archivos consultados ${ }^{65}$, el primer proyecto que se dirigió a establecer un límite a los delitos susceptibles de ser amparados por el Decreto Ley No 2191, data de abril de $1992^{66}$. Este proyecto se planteó bajo la figura de una norma interpretativa de dicho decreto, y establecía dos cuestiones: excluía de la aplicación de la amnistía a los responsables de graves violaciones a los derechos humanos y señalaba que en los casos donde se hubiera dictado el sobreseimiento definitivo, conceder un recurso extraordinario de revisión para que fuera dejado sin efecto. El proyecto fue archivado en mayo de 2001.

En este caso la vía que el legislador propuso no fue anular la ley, aunque más adelante se presentaron proyectos en ese sentido; no restaba eficacia al decreto ley, sino que lo interpretaba estableciendo la imposibilidad que su aplicación a determinados crímenes.

También hubo intentos para anular la Ley de Amnistía, así lo registra el Boletín 4162-07 de abril de 2006, aún en tramitación. El proyecto sugiere varios comentarios que demuestran las muchas dificultades y enfoques envueltos en este asunto. La propuesta se asemeja a lo que se declaró en Argentina. La nulidad del decreto ley afecta toda clase de delitos y no sólo los más graves; pero la propuesta además plantea declarar inaplicable a este caso el principio pro reo, generándose con ello otras dificultades dogmáticas que permiten anticipar su falta de viabilidad.

\section{3. PRoyecto de LeY QUE INTERPRETA el artículo 93 del Código Penal}

La propuesta:

"Artículo único.- Fíjase el verdadero sentido y alcance de las causales de extinción de la responsabilidad penal que se establecen en el artículo 93 del Código Penal, en orden a que deberá entenderse que la amnistía, el indulto y la prescripción de la acción penal y de la pena no serán aplicables a los crimenes y simples delitos que constituyen genocidio, crimenes de lesa humanidad y de guerra, contemplados en los tratados internacionales ratificados por Chile y que se encuentran vigentes"67.

\footnotetext{
3491-07, de 7 abril de 2004. Proyecto de reforma constitucional destinado a permitir el reconocimiento de la jurisdicción de tribunales internacionales. Etapa: discusión general; Boletín 2912 (refundido con el 3191); Boletín 2659-17 de 18 de enero de 2001. Modifica Ley № 18.962 Orgánica Constitucional de enseñanza para promover derechos humanos. Etapa: primer informe comisión. Boletín 2305-07. Archivado.

${ }^{65}$ Página web del Congreso de Chile: senado.cl visitada la semana del 13 al 17 de octubre de 2008.

${ }^{66}$ Vid.: Boletín 654-07. Moción iniciada por los senadores: Jaime Gazmuri, Rolando Calderón, Ricardo Núñez y Hernán Vodanovic.

${ }^{67}$ Boletines 3345-07 y 3959-07, refundidos.
} 
El proyecto pretende hacer frente a las críticas planteadas a los distintos ensayos legislativos. Una ley de esta naturaleza, han dicho sus autores, viene a aclarar el sentido y alcance de estas instituciones respecto a ciertos crímenes en relación a los cuales el Estado ya había asumido determinados compromisos; de manera que al momento de dictarse (la amnistía) o declararse (por los jueces) la extinción de la responsabilidad penal, los poderes públicos ya estaban vinculados a esos compromisos internacionales y, por tanto, limitados en sus términos. La propuesta ha sido largamente debatida, primero en la Cámara de Diputados y luego en la de Senadores. Aprobada primero por la Cámara de Diputados, ha sido posteriormente declarada "inadmisible por inconstitucional" en la Cámara de Senadores.

Para comprender la posición del legislador en esta materia, se han sistematizado los distintos argumentos que se han planteado en el debate del proyecto de ley.

\section{VI.3.1. Los Debates parlamentarios en la Cámara de Diputados}

En el desarrollo de los debates parlamentarios se pueden distinguir argumentos jurídicos y argumentos políticos para desestimar el proyecto. No se dará énfasis a la argumentación que promueve su aprobación, dado que esta posición recoge en parte los criterios de la doctrina que defiende la tesis de la posición constitucional de los tratados, y que en cuanto al fondo del asunto, considera que debe darse una solución general el problema de la tutela judicial de las violaciones graves a los derechos humanos, tesis con la que, por lo demás, coincidimos.

Los argumentos jurídicos:

i) Una ley interpretativa del artículo 93 modifica la Constitución. Para su aprobación se requiere el mismo quórum de una reforma constitucional equivalente a los 3/5 de los Diputados y Senadores en ejercicio:

"Estos proyectos de interpretación sólo tienen el título de tales. En realidad, en su forma $y$ en su fondo, modifican una norma constitucional... En consecuencia, los proyectos en debate modifican una norma constitucional. Por eso, para aprobarlos se requiere el quórum de los tres quintos de los miembros en ejercicio de cada cámara... La moción contenida en el boletín $N^{\circ} 3959-07$ que pretende explicar el artículo 93 del Código Penal, que se refiere a la extinción de la responsabilidad penal, y entre cuyas causales figuran la amnistía y la prescripción, puede resultar sorprendente para quien no sea experto en materias jurídicas, puesto que en el texto en estudio se interpreta esa norma en vez de modificarla para establecer inamnistiabilidad e imprescriptibilidad de los delitos 
de lesa humanidad. Aqui hay una modificación de la norma; no una interpretación. ... Si los autores son partidarios de establecer delitos inamnistiables e imprescriptibles ...planteen derechamente la modificación del Código Penal y de la Constitución; pero no propongan modificar una norma para interpretarla - de eso sólo tiene el título...."

ii) La norma interpretada será aplicada de forma retroactiva, afectándose con ello el principio de legalidad garantizado en la Constitución:

"Las normas penales sólo pueden regir para el futuro. Aqui, en el fondo, se pretende establecer la retroactividad de la ley penal, contraria al ordenamiento jurídico vigente $y$ al estado de derecho de siempre en Chile... Por otra parte, es necesario insistir en que, aunque se trataren válidamente de una interpretación de la ley, ella no puede producir el efecto antes explicado en materia penal..." ${ }^{\text {. }}$.

iii) Las leyes de amnistía son inderogables:

"En segundo lugar, la inderogabilidad de una ley de amnistía. Como consecuencia de lo anterior, las leyes de amnistía son inderogables, y una ley que hiciere tal cosa sería inconstitucional, por infringir la garantía de la irretroactividad de la ley penal"

iv) Una ley no puede imponer otras restricciones a la amnistía y el indulto que las previstas en la Constitución:

"... la facultad de dictar leyes de amnistía y otorgar indultos está consagrada en la Constitución y no admite restricciones impuestas por ley. Hay sólo dos causales de extinción de la responsabilidad penal que están tratadas a nivel constitucional: la amnistía y el indulto... Las leyes que concedan indultos generales y amnistías requerirán siempre de quórum calificado. No obstante, este dictar amnistía es amplia y no está sujeta a restricciones. La ley no puede imponer restricciones a la norma constitucional no previstas expresamente en la Carta Fundamental. En cuanto al indulto, es igualmente claro, porque si bien se autoriza a la ley para dictar las normas con arreglo a las cuales el Presidente puede conceder indultos particulares, ello en ningún caso autoriza a excluir ciertos delitos de la facultad presidencial..." $"$.

${ }^{68}$ Diputado Alberto Cardemil, Cámara de Diputados, Legislatura 354, sesión de 31 de octubre de 2006. // En el mismo sentido: Diputado Jorge Ulloa. Cámara de Diputados, Legislatura 354, sesión de 31 de octubre de 2006.

${ }^{69}$ Diputado Alberto Cardemil, Cámara de Diputados, Legislatura 354, sesión de 31 de octubre de 2006. // En el mismo sentido:Diputado Ward, Cámara de Diputados, Legislatura 354, sesión 108 de 14 de diciembre de 2006.

${ }^{70}$ Diputado Ward, Cámara de Diputados, Legislatura 354, sesión 108 de 14 de diciembre de 2006.

${ }^{71}$ Diputado Ward, Cámara de Diputados, Legislatura 354, sesión 108 de 14 de diciembre de 2006. 
v) La mejor solución jurídica y constitucionalmente viable, es que sean los jueces los que decidan en este asunto:

“Cuál es el fin fundamental de interpretar el artículo 93 del Código Penal? El propósito indisimulado, porque asi lo han manifestado los autores de la moción, es evitar la aplicación de la ley de amnistía. Me parece que la pretensión es legitima, siempre y cuando, los caminos que para ello se elijan se encuadren en la Constitución y la ley... A mi juicio, son cuatro los caminos, los que conocimos cuando se discutió, en comisiones y en Sala, el fallo de la Corte Interamericana de Derechos Humanos sobre el caso Almonacid. Un camino es no hacer nada. Es el más eficaz e, indiscutiblemente, correcto desde el punto de vista jurídico y que, según veremos más adelante, beneficia cada día más la tesis de los que proponen el proyecto. El segundo camino es anular la ley de amnistía. Este es absolutamente improcedente... El tercer camino es el de la derogación, que es legítimo, pero que choca con la irretroactividad de la ley penal, principio básico del derecho penal. En consecuencia, pudiendo derogarse, no tendría ningún sentido práctico... El cuarto camino es el de la interpretación de la ley, que es el que eligieron los autores de la moción. En mi opinión, no está en discusión la facultad que tiene el Poder Legislativo de interpretar la ley. Creo que eso es posible, pero debe enmarcarse en los principios básicos de lo que debe entenderse por interpretación de la ley, porque la puede hacer el Poder Legislativo y la debe hacer el Poder Judicial. Sin embargo, hay otra cuestión fundamental. La interpretación de la ley que hace el legislador tiene por finalidad que la ley interpretativa se aplique desde sus inicios; o sea, quiere decir que cuando se dictó el artículo 93 del Código Penal en 1874 ya existía el propósito que recoge la ley interpretativa que estamos discutiendo. Me parece que esto es enteramente inaceptable, señor Presidente, porque está fuera de discusión que la imprescriptibilidad e inamnistiabilidad de los delitos de lesa humanidad $y$ de guerra es un tema que en el derecho internacional se empezó a discutir recién en la segunda mitad del siglo XX, mientras que el Código Penal se dictó en 1874, es decir, a fines del siglo XIX... ${ }^{m 2}$.

vi) Cuestionamiento de los contenidos, alcance y validez de las normas del Derecho Internacional en el ordenamiento interno:

"En los proyectos refundidos se hace un largo análisis de los antecedentes de derecho internacionaly doctrinarios que verifican que los delitos de lesa humanidad son inamnistiables e imprescriptibles -esta es una tendencia del derecho internacional-; pero, al mismo tiempo, se sostiene que este planteamiento ha sido recogido y es plenamente aplicable en nuestro derecho. Luego, aqui hay una flagrante contradicción. Si esta conclusión está recogida en la legislación chilena, no se comprende para qué va a ser necesario este proyecto. Nosotros

${ }^{72}$ Diputado Eluchans. Cámara de Diputados, Legislatura 354, sesión 108 de 14 de diciembre de 2006. 
tenemos otra posición. La tendencia del derecho internacional es a eliminar la amnistía y la prescripción. Es una tendencia firme y clara; pero no es categórico -y por eso se han inventado estos proyectos de ley-que ella rija y deba ser aplicable en Chile, según su ley positiva... Ni los crimenes de guerra ni los de lesa humanidad existen en la ley chilena y, sin embargo, el proyecto se hace cargo de ellos. Entonces, mientras no estén tipificados es tremendamente discutible...que se declaren imprescriptibles como aqui acontece. Resulta dificil declarar imprescriptibles delitos no tipificados en la ley nacional... Los proyectos mencionan la Convención sobre la Imprescriptibilidad de los Crímenes de Guerra y de los de Lesa Humanidad, de 26 de noviembre de 1968... Queremos dejar establecido que dicho convenio, a la fecha, no ha sido ratificado por Chile, sin perjuicio de agregar que se trata de un convenio que no tiene muchas ratificaciones por otros paises" ${ }^{\prime \prime 3}$.

vii) A favor de su aprobación: el cumplimiento de las obligaciones contraídas por el Estado, concretamente, la de promover los derechos contenidos en tratados:

"Nuestro pais ha participado en foros mundiales y ha suscrito tratados internacionales que dicen relación con el desarrollo y promoción de los derechos humanos. El inciso segundo del artículo $5^{\circ}$ de la Constitución Política establece: 'El ejercicio de la soberanía reconoce como limitación el respeto a los derechos esenciales que emanan de la naturaleza humana. Es deber de los órganos del Estado respetar y promover tales derechos.... Por ello, con la aprobación de esta norma interpretativa, el Congreso Nacional no está haciendo otra cosa sino que cumplir con lo dispuesto en el artículo $5^{\circ}$ de la Constitución Política, que prescribe la obligación de promover estos derechos reconocidos en nuestro derecho interno y en los tratados internacionales suscritos por Chile... No hay una nueva ley, sino una interpretación de una norma antigua, conforme al espiritu que ha inspirado a nuestro pais, por ende, al Congreso Nacional, al ratificar tratados y al suscribir compromisos internacionales en materia de derechos humanos. Debemos ser consecuentes con la palabra que hemos empeñado en los distintos foros internacionales en los que hemos tenido activa participación. Y ésta no es sólo una idea personal, sino también la opinión de un grupo de abogados con quienes hemos comentado este trascendental proyecto..." ${ }^{\prime 4}$.

Los argumentos políticos:

i) La transición chilena a la democracia se construyó sobre la base de aceptar la amnistía de 1978 y que el poder judicial ejerciera sus atribuciones caso a caso:

\footnotetext{
${ }^{73}$ Diputado Alberto Cardemil. Cámara de Diputados, Legislatura 354, sesión de 31 de octubre de 2006//. En el mismo sentido: Diputado Ward. Cámara de Diputados, Legislatura 354, sesión 108 de 14 de diciembre de 2006.

${ }^{74}$ Diputado Enrique Jaramillo. Cámara de Diputados, Legislatura 354, sesión 108 de 14 de diciembre de 2006.
} 
"Cada país tiene su historia, su proceso. La amnistía en Chile favoreció a varios sectores, benefició a muchas personas, civiles y militares, y la transición chilena ha consistido precisamente en que cada juez, caso a caso... Hay sectores de la Concertación... a los que nunca les ha gustado la forma cómo ha operado la transición chilena; que lo que quieren es terminar con la institución de la amnistía y con la de la irretroactividad de la ley penal que son normas esenciales de un Estado de Derecho en forma. Estos estamentos son hoy los que tienen influencia y mayor figuración en el actual Gobierno, y su idea, a través de este proyecto de ley, es no meterse en la discusión que hoy divide a la Concertación a propósito de la sentencia de la Corte Interamericana; si se va a avanzar en una derogación o en una ley de nulidad..." $"$ "5.

ii) Existe injerencia de tribunales externos y ajenos al país en este asunto:

"Estamos ante una situación grave. Sostengo que esta acción, que se ha intensificado... ha llevado a Chile a una especie de interdicción internacional: los chilenos estamos sujetos a lo que resuelvan los tribunales internacionales. Es evidente que los intereses políticos de la Concertación se trenzan con los de los abogados del Estado de Chile -ya nos vamos a meter en este tema-, que están mucho más preocupados de plegarse a los argumentos de los demandantes que de defender el interés chileno. El considerando 92 del fallo de la Corte Interamericana de Derechos Humanos en el caso Almonacid Arellano versus el Estado de Chile, ahorra todo comentario. En él se señala que nuestros abogados, que debieron defender el interés chileno, consideran que la ley de amnistía no tiene validez jurídica ni ética, dando así el argumento con el que se condenó al Estado de Chile. ¡Dios nos guarde de que la Cancillería nos siga defendiendo como lo está haciendo, porque seguiremos perdiendo juicios!..." ${ }^{m 6}$.

iii) La actuación del régimen militar fue valiosa y excepcional. Su intervención fue el resultado de la confrontación que se vivió en el país durante el gobierno de Salvador Allende:

"Parto por señalar que, al parecer, para algunos Chile nació el 11 de septiembre de 1973 $y$ antes nunca ocurrió nada. Quien habla tenía 14 años en esa época y, a pesar de su corta edad, se daba cuenta de la forma como el país, nuestro amado Chile, se encontraba destruido por la odiosidad de clases encarnada en las ideas que defendía mi querido colega Aguiló. En ese entonces, hubo violencia y odio de clases, y la democracia que hoy todos alabamos, muchos no la querían, porque quienes tenían el mismo pensamiento del colega Aguiló en esa época, decian que era una democracia burguesa y que habia que destruirla. Por lo tanto, para ellos todo era lícito, incluido el uso de las armas. Varios de los que están enfrente estuvieron por la vía de usar las armas... Pero, el caso es que Chile, que vivió

${ }^{75}$ Diputado Alberto Cardemil. Cámara de Diputados, Legislatura 354, sesión de 31 de octubre de 2006.

${ }^{76}$ Diputado Alberto Cardemil. Cámara de Diputados, Legislatura 354, sesión de 31 de octubre de 2006. 
otrora una situación excepcional, que desgraciadamente tuvo graves consecuencias para sus habitantes, se vio enfrentado, después de muchos años, a seguir discutiendo lo que pasó en esa época. Debo decir-lo más claro que pueda-que, simplemente, si no hubiera existido la Unidad Popular, no hubiera existido un gobierno militar. Por algo llegó el gobierno militar. En todo caso, estoy segura de que nunca más va a haber otro gobierno militar, pase lo que pase, aunque el país esté en ruinas, destruido, porque los militares jamás se van a exponer nuevamente a ser victimas de todas las injusticias posteriores. En ese gobierno, a la larga, efectivamente, hubo abusos a los derechos humanos y yo, hija de un oficial de las Fuerzas Armadas, no supe qué pasaba mientras pasaba"r7.

iv) El proyecto busca la venganza y alimentar las diferencias y la discordia entre los ciudadanos:

"Todos sabemos que este proyecto apunta, obviamente, al revanchismo, a la venganza y a mantener el odio en nuestro pais. Cuando he conversado con algunos diputados con los cuales me siento cercano sobre situaciones personales que los han afectado, he sido el primero en reconocer y comprender su dolor... Si los tribunales de justicia no han aplicado sanciones no es por culpa de la Oposición ni porque haya dictadura. Estamos en democracia y los jueces han ejercido sus funciones de manera independiente... Le guste o no le guste a la Izquierda, en Chile casi la mitad de los chilenos valora la obra gruesa del gobierno militar, a pesar de todos sus errores. Esa obra gruesa es la que va a permitir, no formar un partido pinochetista, sino que dar a los hechos el lugar que les corresponde. A la gente se le olvidó la Unidad Popular; a la gente se le olvidó lo que pasó en el gobierno del Presidente Allende" ${ }^{\text {" }}$.

Los argumentos políticos a favor de la aprobación del proyecto señalaron que su aprobación era un imperativo ético, histórico desde que terminó la dictadura y que permite verdaderos avances hacia un país democrático y republicano ${ }^{79}$.

Como se desprende de lo expuesto, la discusión se centró en los hechos del pasado; no existe un análisis de la norma que mire hacia el futuro y refuerce la tutela judicial en estos casos. Pero incluso respecto a los hechos del pasado, poco dicen los legisladores respecto a los criterios aplicados por los jueces en esta materia; se dijo que la solución más adecuada es que siga siendo el poder judicial el que resuelva el problema, pero no se analizan los criterios que ellos han aplicado.

${ }_{77}$ Diputada María Angélica Cristi. Cámara de Diputados, Legislatura 354, sesión de 31 de octubre de 2006.

${ }^{78}$ Diputado Iván Moreira. Cámara de Diputados, Legislatura 354, sesión 108 de 14 de diciembre de 2006.

${ }^{79}$ Vid.: Diputada Isabel Allende. Cámara de Diputados, Legislatura 354, sesión 108 de 14 de diciembre de 2006. 
A pesar de las objeciones, el proyecto fue aprobado por la Cámara de Diputados y despachado a la Cámara de Senadores para continuar su tramitación, pero una vez en la Cámara Alta, el proyecto fue desechado por inconstitucionalidad de forma. Esta decisión motiva varias reflexiones que serán tratadas en el siguiente apartado.

\section{VI.3.2. Los debates en el Senado}

Luego de recibir el proyecto aprobado por la Cámara de Diputados, el Presidente de la Cámara de Senadores en decisión ratificada por la mayoría de sus miembros, declaró que el proyecto de interpretación del art. 93, era "inadmisible" por inconstitucional. La objeción obedeció a que conforme a la Constitución, el proyecto debió iniciarse en esa Cámara y no en la de Diputados.

Según las Actas Oficiales de la Cámara del Senado, sesión de 4 de junio de 2008, el Senador de la Unión Demócrata UDI, Jorge Arancibia, una vez iniciada la presentación del proyecto, solicitó que se rechazara por inadmisible ya que según el artículo 65 de la Constitución ${ }^{80}$ las leyes que se relacionan con amnistías e indultos generales sólo pueden tener origen en la Cámara del Senado ${ }^{81}$.

El Presidente de la Cámara declaró admisible la solicitud" 82 , pero en la siguiente sesión se vio obligado a someter esa decisión a votación, dado que según la interpretación a que se llegó en la Cámara Alta, esta decisión debía ser asumida por mayoría.

Los senadores que consideraron inadmisible el proyecto plantearon dos asuntos: a) el Presidente del Senado es competente para realizar esta declaración ${ }^{83}$, y b) no se discute sobre el fondo del proyecto, sino el apego a los procedimientos establecidos ${ }^{84}$.

El grupo de senadores que defendió la constitucionalidad del proyecto, señaló:

i) El Presidente del Senado no tiene competencia para declarar la inconstitucionalidad, el órgano competente es el Tribunal Constitucional ${ }^{85}$.

\footnotetext{
${ }^{80}$ Artículo 65 de la Constitución: "Las leyes pueden tener origen en la Cámara de Diputados o en el Senado, por mensaje que dirija el Presidente de la República o por moción de cualquiera de sus miembros... Las leyes sobre amnistía y sobre indultos generales sólo pueden tener origen en el Senado...”.

${ }^{81}$ Senador Larraín. Sesión 24 de 4 de junio de 2008.

${ }^{82}$ Sesión 24 de 4 de junio de 2008. En el mismo sentido: Senador Espina, Sesión 24 de 4 de junio de 2008.

${ }^{83}$ Senador Adolfo Zaldívar. Cámara de Senadores. Sesión 28 de 18 de junio de 2008.

${ }^{84}$ Senador Adolfo Zaldívar. Cámara de Senadores. Sesión 28 de 18 de junio de 2008.

${ }^{85}$ Vid.: Senador Escalona. Cámara de Senadores. Sesión 28 de 18 de junio de 2008.
} 
ii) En ninguno de los trámites de comisiones a que se sometió el proyecto tuvo lugar ninguna observación en este sentido ${ }^{86}$.

iii) La Cámara de Diputados tiene iniciativa en estos casos, porque no se trata de un proyecto que conceda amnistía o indulto. Por vía de la interpretación se regulan las causales de extinción de la responsabilidad penal, que son materias de codificación y conforme a la Constitución deben ser tramitadas ante la Cámara de Diputados ${ }^{87}$.

Frente a esta declaración, el 17 de junio de 2008 la Cámara de Diputados dirigió un oficio a la Cámara Alta, donde señala que no puede aceptar la resolución del Senado, por tanto, reenvía el proyecto para su aprobación o rechazo, o bien, para que dirija las consultas ante el órgano de control correspondiente ${ }^{88}$. A la fecha, no existe aún la respuesta que sobre este asunto adoptará la Cámara de Senadores.

Sobre esta decisión se plantean los siguientes comentarios:

A) Sobre las facultades de las Cámaras para decidir sobre la constitucionalidad de un proyecto de ley

La cuestión tiene su respuesta en el artículo 93 de la Constitución: "Son atribuciones del Tribunal Constitucional. No 3: Resolver sobre las cuestiones de constitucionalidad que se susciten durante la tramitación de los proyectos de ley o de reforma constitucional y de los tratados sometidos a la aprobación del Congreso".

El legislador no puede actuar como juez y parte en este asunto, especialmente porque existen criterios contrapuestos entre la Cámara de Senadores y la Cámara de los Diputados. Eso no implica que en asuntos de rápida revisión, no puedan hacer observaciones o verificar que la tramitación de las propuestas de ley se ajuste a los procedimientos que establece la propia Constitución. Pero no puede

\footnotetext{
${ }^{86}$ Senador Gazmuri. Cámara de Senadores. Sesión 28 de 18 de junio de 2008.

${ }^{87}$ Senador Gómez. Cámara de Senadores. Sesión 28 de 18 de junio de 2008.

${ }^{88}$ Oficio $\mathrm{N}^{\circ} 7.528$ de 17 de junio de 2008, dirigido por el Vicepresidente de la Cámara de Diputados al Presidente de la Cámara del Senado: "La Cámara de Diputados tomó conocimiento del Oficio № 693/ SEC/08, de 11 de junio de 2008, mediante el cual V.E. comunica a esta Corporación que el Senado declaró inadmisible el proyecto de ley de esta Cámara que adecua la legislación penal chilena a los tratados internacionales en materia de derechos humanos, contenido en el oficio $\mathrm{N}^{\circ} 6.631$, de 14 de noviembre de 2006 (Boletines $\mathrm{N}^{\circ}$ s. 3345-07 y 3959-07). Sobre la materia, acordó devolver el Oficio Nº 693/SEC/08, atendido que admitir que esa Corporación declare inadmisible una iniciativa de ley aprobada por la Cámara de Diputados implica aceptar que el Senado puede crear un nuevo trámite constitucional, no reconocido por la Carta Fundamental, y ejercer una facultad que ésta no le confiere, lo que, por consiguiente, vulnera su artículo $7^{\circ}$. En virtud de las consideraciones precedentes, esta Cámara concluyó que no puede aceptar tal resolución del Senado, por carecer de eficacia jurídica, y que únicamente procede que esa Corporación se pronuncie sobre el proyecto en segundo trámite constitucional o ejerza las acciones ante el órgano de control correspondiente.
} 
"resolver las cuestiones de constitucionalidad", porque son de competencia del Tribunal Constitucional.

B) Sobre la iniciativa exclusiva del Senado en materia de Amnistía e Indultos Generales

Respecto a la naturaleza del proyecto de ley que interpreta el art. 93, durante la tramitación del proyecto, éste se ha denominado como un "Proyecto de ley, que adecua legislación penal chilena a tratados internacionales en materia de derechos humanos". Bajo este título, el proyecto legislativo ha sido planteado como una ley interpretativa del artículo 93 del Código Penal que establece las causales de extinción de la responsabilidad penal. No concede indulto ni amnistía, lo que el proyecto busca es hacer explícita una limitación para ciertos y determinados delitos: genocidio, crímenes de guerra y crímenes de lesa humanidad. No se trata de un proyecto que busque reformar el artículo, se propone como una iniciativa para explicitar una correcta interpretación del art. 93 a la luz de los compromisos que el Estado ha adquirido en esta materia y de conformidad con los criterios desarrollados por la jurisprudencia.

Aclarado que no se trata de conceder, sino de restringir la procedencia de las causales de extinción de la responsabilidad penal en ciertos casos, surge la pregunta: ¿De donde proviene esta limitación? No se trata de una creación del legislador, su antecedente inmediato son los contenidos de obligaciones derivadas de compromisos internacionales y que se dirigen fundamentalmente al juez y al legislador para no aplicar estas causales cuando se trata de graves infracciones a los derechos humanos. Si bien el poder judicial ha desarrollado esta interpretación, el legislador no parece sentirse obligado por los compromisos internacionales sino sólo por normas internas, y este poder no está por encima de los otros poderes públicos, como todos, está obligado por los compromisos internacionales.

En cuanto a la iniciativa legislativa en materia de indultos generales y amnistías, la norma se refiere a amnistías e indultos generales, beneficios que sólo pueden ser concedidos por el legislador, ya que el indulto particular es de competencia del Presidente. Dicho de otra manera, la limitación contenida en la norma no parece referirse a la regulación que puede y debe desarrollarse para esas instituciones, de otra manera bastaría con que dijera: las leyes que se refieren a indultos y amnistías. Por el contrario, si la norma se refiere a la amnistía y al indulto general, hace referencia a su concesión y no a su regulación ${ }^{89}$.

\footnotetext{
${ }^{89}$ En el mismo sentido, el artículo 65 señala que las leyes relativas a tributos sólo pueden tener origen en la Cámara de Diputados. La misma discusión que se acaba de analizar en este caso podría aplicarse a los tributos, que serían de iniciativa exclusiva de la Cámara de Diputados, tanto su regulación como creación. Sin embargo, la práctica en este caso no ha obedecido al mismo criterio. Si este artículo se refiriera a toda materia relativa
} 
Algunas conclusiones sobre esta polémica: la excesiva dilatación de cualquier iniciativa legislativa que se relacione con la tutela judicial de violaciones a los derechos humanos, da fuerza a algunos de los planteamientos que se han desarrollado a lo largo de este trabajo. La Constitución de 1980 con la incorporación de senadores designados -en funciones hasta inicios de 2006- y el sistema binominal para su elección, han asegurado una sobrerrepresentación política para algunos sectores, excluyendo a otras formaciones minoritarias. Y algo ocurre con la representación política: el 57\% de los chilenos afirma que no se siente identificado con ninguna de las coaliciones políticas con presencia parlamentaria en el país ${ }^{90}$.

Es de reconocer que incluso desde 2008 cuando los senadores designados han sido eliminados de la Constitución, la jurisprudencia de los tribunales superiores ha unificado sus criterios en esta materia y cuando comienza a apreciarse la apertura del Tribunal Constitucional hacia el DIDH, esta evolución no ha sido compartida ni asumida por todos los legisladores. Esta resistencia trae a la memoria las reflexiones de José Luis Cea Egaña, que planteaba como el mayor obstáculo para que exista acuerdo sobre el sentido y alcance del inciso segundo del artículo $5^{\circ}$ de la Constitución, las responsabilidades penales por graves violaciones a los derechos humanos ${ }^{91}$.

El legislador, de todos los poderes públicos analizados hasta ahora, se ha desentendido del desarrollo y aplicación del DI en el Derecho interno, ha dejado a los jueces esta responsabilidad y con ello retrasa, ya no exclusivamente el desarrollo normativo de la tutela judicial, también, la posibilidad de que por vía de los tratados se avance en la protección de otros derechos. Pero, quizás, el resultado más perverso de esta falta de acuerdo, sea que los poderes públicos se contradicen, no existe una manera común de enfrentar este problema ni una institucionalidad capaz de resolverlo de una manera general.

La valoración que se acaba de realizar, introduce una cuota de incertidumbre respecto a las verdaderas razones por las que el Senado declaró la inadmisibilidad

\footnotetext{
a tributos (que los regulen y los creen), entonces no ha tenido el mismo tratamiento la iniciativa que el Senador Baldo Prokurica presentó ante la Cámara del Senado como proyecto sobre "Modificación del Código Tributario en lo relativo a derechos del contribuyente", Boletín 3845-05, iniciado en abril de 2005, que ya fue aprobado por el Senado y está ahora en segundo trámite constitucional en la Cámara de Diputados.

${ }^{90}$ Encuesta del Centro de Estudios Públicos, CEP, de junio de 2008. Asimismo, según el Latinobarómetro, Informe de 2008, la evaluación de la opinión pública del Congreso Nacional es la siguiente: Evaluación del Congreso: muy bien y bien, 33\%; Confianza en el Congreso: mucha o algo, 32\%; Evaluación de los partidos políticos: muy bien y bien, 20\%; Confianza en los partidos políticos: mucha o algo, 16\%; Participación política: 3\%. Fuente: www.latinobarómetro.org.

${ }^{91}$ CeA (1997) pp. 81-91.
} 
del proyecto por inconstitucionalidad. No parece que se trate simplemente de objeciones de forma, más bien esta oposición evidencia el interés por evitar los costos políticos de una decisión en esta materia.

Los derechos de tratado, pese a los avances que se han producido en el Tribunal Constitucional y los tribunales superiores, no tienen en definitiva un tratamiento claro, para unos poderes operan como límite, para otros son materias ajenas al ordenamiento nacional, y suponen obligaciones que el Estado puede o no puede desarrollar. La actuación del legislador en este sentido, se ajusta más al texto original de la Constitución de 1980 y menos al espíritu y los valores que incorporó el reformador democrático.

\section{CONCLUSiones}

El deber de prevenir, juzgar y sancionar violaciones graves es un principio internacional de naturaleza compleja, que ha generado problemas y tensiones en su aplicación en Chile y otros países por múltiples razones. Su desarrollo jurisprudencial ha impulsado una redefinición del principio de legalidad en lo que se refiere a la perseguibilidad de estos delitos.

Es en el Derecho Internacional donde más se han desarrollado las normas que obligan al enjuiciamiento de estos actos, y sólo recientemente algunos ordenamientos han comenzado a incluir normas que tipifican delitos y hacen operativo el deber de persecución. Dicho esto, a pesar de que en ordenamientos como el chileno no se desarrollen este tipo de normas, el Derecho Internacional ha sido la base a partir de la cual los jueces han dado cumplimiento a esa obligación. El Derecho Penal Internacional ha transformado la manera de comprender principios clásicos como el de legalidad en materia penal, y ello ha dado lugar a un desarrollo doctrinario y jurisprudencial que va por delante del desarrollo normativo del deber.

La ausencia de normas que limiten la amnistía y la prescripción propicia las tensiones entre el deber de juzgar y sancionar y el principio de legalidad. Si esas leyes existieran desde el momento en que se contrajeron las obligaciones internacionales, no se habrían producido los problemas que se han examinado en este trabajo. Esta carencia tiene, además, otros efectos contradictorios en el tratamiento de la reparación y la pena. Para ambas cuestiones es fundamental que se unifiquen criterios y en este sentido el legislador debe hacer un aporte fundamental.

En lo que se refiere a la transición y la manera en que se resuelven los crímenes de la dictadura, si bien la actuación del poder judicial ha sido clave para avanzar en su resolución, el poder legislativo diseñado en la Constitución de 1980 y las mayorías que produce, no contribuyen a una solución general al problema. Argumentando problemas de armonización y contradicción entre derechos, los 
legisladores delegan en el poder judicial la solución del problema, pero su oposición a legislar en esta materia, por un lado niega el cumplimiento de las obligaciones que se derivan de tratados y, por otro, expresa su voluntad de evitar los costos políticos que su intervención puede acarrear. De allí la importancia de dar una solución al problema, porque no se relaciona sólo con las violaciones graves a los derechos humanos, sino con todo el sistema de derechos que la Constitución de 1980 reconoce.

Finalmente, en lo que va de 2010, en al menos dos ámbitos se han planteado nuevas interrogantes: la posibilidad de que los responsables de estos delitos puedan beneficiarse con el indulto y que quienes están privados de libertad en causas por graves violaciones a los derechos humanos, puedan acceder a beneficios carcelarios. Precisamente, la omisión de la mayoría de los legisladores, que se concreta en el abandono del proyecto de ley para reformar el artículo 93 del Código Penal, abre la brecha por la que ahora se intenta avanzar en el sentido contrario a los compromisos asumidos en el ámbito internacional.

Por eso la necesidad de definir, en un debate abierto y respetando los compromisos asumidos y los criterios definidos por los jueces, la inaplicabilidad de las causales de extinción de la responsabilidad penal a los responsables de crímenes atroces y en cuanto a los beneficios carcelarios, conviene analizar las normas que en este sentido contempla el Estatuto de la Corte Penal Internacional, que si bien no son aplicables directamente, deben ser analizadas como un criterio interpretativo y donde se imponen altos estándares y criterios restrictivos a la posibilidad de reducir la pena en estos casos.

\section{BiBLIOGRAFíA}

Ambos, Kai; Malarino, Ezequiel; Elser, Gisela Editores (2008): Jurisprudencia Latinoamericana sobre Derecho Penal Internacional (Montevideo, Fundación Konrad-Adenauer) p. 475.

Bascuñán, Antonio (2008): Derechos Fundamentales y Derecho Penal [Visitado el 15 de abril de 2008], disponible en: http://islandia.law.yale.edu/sela/ sbascunan.pdf.

Boletín de Documentación, No 27 septiembre-diciembre (2006) II. Argentina y su transición a la democracia: procesos de verdad y justicia. Centro de Estudios Políticos y Constitucionales, España [visitado el 15 de enero de 2008], formato electrónico: http://www.cepc.es/catalogo_documentos_electronicos. asp? IdClasificacion $=112 \&$ IdCCatalogados $=319$

Bustos, Juan (2007): "Inadmisibilidad de Autoamnistías en el Derecho Penal”, en Gaceta Jurídica (No 326/agosto) pp. 7-23. 
Cea Egaña, José Luis (1997): "Los Tratados de Derechos Humanos y la Constitución Política de la República”, en Ius et Praxis (año 2 No 2) pp. 81-91.

Cumplido Cereceda, Francisco (2003): "La reforma Constitucional de 1989 al inciso $2^{\circ}$ del artículo $5^{\circ}$ de la Constitución: sentido y alcance de la Reforma. Doctrina y jurisprudencia”, en Ius et Praxis ( Vol. 9 No 1) pp. 365-374.

Feldens, Luciano (2005): A Constituiçao Penal a dupla face da proporcionalidade no controle de normas penais. (Porto Alegre, Brasil, Livraria do Advogado Eitorial Ltada.) p. 223.

FernÁNDEZ, Miguel Ángel (2003): "Visión Prospectiva en Relación con la Regulación Constitucional de los Tratados Internacionales", en Ius et Praxis (Vol. 9 Número 1) pp. 485-511.

Fernández González, Miguel Ángel (2010): "La aplicación por los tribunales chilenos del Derecho Internacional de los Derechos Humanos", en Estudios Constitucionales año 8. No 1, pp. 425-442.

Fernández Neira, Karina; Sferraza Taibi, Pietro (2009): "La aplicación de la prescripción gradual en casos de violaciones a los derechos humanos"; en Estudios Constitucionales año 7. No 1, pp. 299-330.

FERnÁndeZ Pons, Xavier (2002): "El principio de legalidad penal y la incriminación internacional del individuo". Revista Electrónica de Estudios Internacionales [fecha de consulta, 10 de abril de 2009]. Disponible en http://www.reei.org/ reei5/reei.5.htm

Henríquez Viñas, Miriam Lorena (2008): “Jerarquía de los tratados de derechos humanos: análisis jurisprudencial desde el método de casos”, en Estudios Constitucionales año 6. No 2, pp. 73-119.

INFANTE CAFFI, María Teresa (1996): Los Tratados en el Derecho Interno chileno: El efecto de la Reforma Constitucional de 1989, Visto por la Jurisprudencia chilena, en Revista Chilena de Derecho (Vol. $23 \mathrm{No}^{\text {s. }} 2$ y 3, mayo-agosto) pp. 277-297.

Irigoin BarRenne, Jeannette (1996): "La Convención Americana de Derechos Humanos como Derecho Interno Chileno", en Revista Chilena de Derecho (Vol 23, Nos. 2 y 3, mayo-agosto) pp. 299-307.

Jescheck, H.H. (1981). Tratado de Derecho Penal. Parte General. Volumen Primero (Bosch, Barcelona) p. 696.

Matus A., Jean Pierre (2006): "Informe pericial ante Corte Interamericana de Derechos Humanos, sobre aplicación jurisprudencial de decreto ley 2191 de amnistía”, en Ius et Praxis (Vol. 12, No 1) pp. 275-296. 
Mohor Abuad, Salvador (1990): "Elementos de Juicio para la Interpretación del artículo $5^{\circ}$ inciso 20 de la Constitución de 1980", en Revista de Derecho Público, (No 47-48) pp. 53-193.

NASH Rojas, Claudio: "La Incorporación de los Instrumentos Internacionales de Derechos Humanos en el Ámbito Nacional: la Experiencia de Chile. Compilación de la Facultad de Derecho de la Universidad de Chile" (visitado el 10 de noviembre de 2008). Formato electrónico: http://www.cdh.uchile.cl/ conferencias_charlas/Nash/Derechos_Humanos-Unicef.pdf .

Nogueira Alcalá, Humberto (2007): "La Dignidad Humana, los Derechos Fundamentales, el Bloque Constitucional de Derechos Fundamentales y sus Garantías Jurisdiccionales", en Gaceta Jurídica, (Santiago de Chile abril No 322) pp. 32-67.

NúNEz Pobrete, Manuel (2009): "La función del derecho internacional de los derechos de la persona en la argumentación de la jurisprudencia constitucional: Práctica y principios metodológicos", en Revista de Derecho de la Pontificia Universidad Católica de Valparaíso, No 32, pp. 487-529.

Orrego Vicuña, Francisco (1998): La aplicación del Derecho Internacional de los Derechos Humanos por los Tribunales Nacionales. Apuntes de clases, Facultad de Derecho Universidad de Chile (no publicado).

PeÑA, Marisol (2008): "La aplicación del Derecho Internacional de los Derechos Humanos por el Tribunal Constitucional Chileno", en Estudios Constitucionales (Año 6, No 1) pp. 205-222.

Rey Martínez, Fernando (1989): "El criterio interpretativo de los Derechos Fundamentales conforme a normas internacionales (Análisis del artículo 10.2 CE)", en Revista General de Derecho. Madrid, pp. 3611-3622.

Ríos, Lautaro (1998): Jerarquía Normativa de los Tratados Internacionales sobre Derechos Humanos, en Gaceta Jurídica (mayo No 215) pp. 7-14.

SAIZ ARNAIZ, Alejandro (1999): La apertura constitucional al Derecho Internacional de los derechos humanos. El artículo 10.2 de la Constitución española (Madrid, Consejo General del Poder Judicial).

Silva Bascuñán, Alejandro (1997): Tratado de Derecho Constitucional. Tomo IV (Santiago de Chile, Editorial Jurídica) 376 pp.

VAN WeEZEL, Alex (2007): “Inadmisibilidad de las 'leyes interpretativas' in malam partem en Materia Penal”, en Gaceta Jurídica (No 323/mayo), pp.14-30.

Zúniga Urbina, Francisco (2007): "Comentario a la Sentencia en el 'Caso Molco' de la Excma. Corte Suprema, de 13 de diciembre de 2006”, en Estudios Constitucionales año 5 No 1, pp. 525 a 531. 


\section{JURISPRUDENCIA}

Tribunal Constitucional de Chile Rol No 226, sentencia de 30 de octubre de 1995.

Tribunal Constitucional de Chile Rol No 383, sentencia de 5 de septiembre de 2003.

Tribunal Constitucional de Chile Rol No 481, sentencia de 4 de julio de 2006.

Tribunal Constitucional de Chile Rol No 576, sentencia de 24 de abril de 2007.

Tribunal Constitucional de Chile Rol No 519, sentencia de 5 de junio de 2007.

Tribunal Constitucional de Chile Rol No 728, sentencia de 3 de julio de 2007.

Tribunal Constitucional de Chile Rol No 807, sentencia de 4 de octubre de 2007.

Tribunal Constitucional de Chile Rol No 786, sentencia de 30 de enero de 2008.

Tribunal Constitucional de Chile Rol No 740, sentencia de 18 de abril de 2008.

Tribunal Constitucional de Chile Rol No 1.340-09, sentencia de 29 de septiembre de 2009.

Juan Contreras Sepúlveda y otro (2004): Corte Suprema 17 de noviembre de 2004.

Ricardo Rioseco Reyes con Joaquín León Rivera (2005): Corte Suprema 4 de agosto de 2005.

Estado de Chile; Miriam Luz Ancacura; Pafián; María Ester Hernández Martínez; con Sergio Héctor Rivera Bozzo (2007). Corte Suprema 5 de septiembre de 2007.

Fiscalía Judicial; María Angélica Rivera Sánchez; Juan Patudo Rivera Sánchez; Gaby Lucia Rivera Sánchez; Jovina del Carmen Rivera Sánchez; Olga Matilde Rivera Sánchez; Cecilia de las Mercedes Rivera Sánchez; Juan Carlos Rivera Sánchez con Freddy Enrique Ruiz Bunger; Carlos Arturo Madrid Hayden; Alvaro Julio Federico Corbalán Castilla; Sergio Antonio Díaz López (2007): Corte Suprema 30 de julio de 2007.

Luisa Faustina Joo con Miguel Krassnoff Martchenko; Luis Manuel Moren Brito; Osvaldo Enrique Romo Mena; RolfGonzalo Wenderoth Pozo; Basclay Humberto Zapata Reyes (2007): Corte Suprema 27 de junio de 2007.

Pizani Burdiles, Gladys del Carmen y otra con Fisco de Chile (2003): Corte Suprema 15 de abril de 2003. 
Domic Bezic y otros con Fisco (2002): Corte Suprema 15 de mayo de 2002. Julio Artemio Vergara Jofré; Hugo Antonio Vergara Muñoz; Alberto Santander Muñoz con Fisco de Chile (2004): Corte Suprema 28 de julio de 2004.

Hilda Elena Espinoza Figueroa; Esteban Rodolfo Rioseco Espinoza con Fisco de Chile (2006): Corte Suprema 11 de octubre de 2006.

Paulino Flores Rivas y otros (2004): Corte Suprema13 de diciembre de 2006.

Mario Urrutia Villa con Freddy Enrique Ruiz Bunger y otros (2007).Corte de Apelaciones de Santiago 2 de agosto de 2007.

Eduvina Bedi Ríos Vejar con Augusto Pinochet Ugarte; Sergio Arellano Stark; Odlanier Mena Salinas; Luis Guillermo Carrera Bravo; René Iván Bravo Llanos (2007): Corte de Apelaciones de Santiago 16 de agosto de 2007.

Ernesto Yoliztly Lejderman Avvalos con Fernando Guillermo Santiago Polanco Gallardo y otros (2007): Corte de Apelaciones de Santiago 18 de diciembre de 2007. Hirma Villagra Castro con Juan Manuel Guillermo Contreras Sepúlveda; Marcelo Luis Manuel Morel Brito (2007): Corte de Apelaciones de Santiago10 de enero de 2008.

\section{Corte Interamericana de Derechos Humanos}

Caso Barrios Altos vs. Perú. Serie C No 75. Sentencia de 14 de marzo de 2001.

Caso Almonacid Arellano vs. Chile. Serie C No 154. Sentencia de 26 de septiembre de 2006.

Tribunal Constitucional español: STC 84/1989; STC 34/2008; STC 52/2008; STC 123/2008.

\section{Congreso Nacional}

Boletín 1657, 19 de julio de 1995.

Boletín 656-07, 7 de abril de 1992.

Boletín 1681-07, 22 de agosto de 1995.

Boletín 1718-07, de 11 de octubre de 1995.

Boletín 1265-10, de 6 de julio de 1994.

Boletín 3317-07, de 26 de agosto de 2003.

Boletín 3345-07, de 9 de septiembre de 2003, refundido con Bol. 3595.

Boletín 3959, de 30 de agosto de 2005.

Boletín 3980-07, de 7 de septiembre de 2005.

Boletín 4162-07, de 21 de abril de 2006.

Boletín 5918-07, de 11 de junio de 2008. 
Boletín 4768-07, de 2 de enero de 2007.

Boletín 4727-07, de 13 de diciembre de 2006.

Boletín 3491-07, de 7 abril de 2004.

Boletín 2912 (refundido con el 3191).

Boletín 2659-17, de 18 de enero de 2001.

Cámara de Diputados. Sesión 31 de octubre de 2006.

Cámara de Diputados. Sesión 108 de 14 de diciembre de 2006.

Cámara del Senado. Sesión 24 de 4 de junio de 2008.

Cámara del Senado. Sesión 28 de 18 de junio de 2008.

\section{AbreViaturas}

CADH : Convención Americana de Derechos Humanos

CE : Constitución Española

$\mathrm{CIDH} \quad$ : Comisión Interamericana de Derechos Humanos

Corte IDH : Corte Interamericana de Derechos Humanos

DI : Derecho Internacional

DIDH : Derecho Internacional de los Derechos Humanos

D.L. : Decreto Ley

DINA : Dirección Nacional de Inteligencia

DPI : Derecho Penal Internacional

PIDCP : Pacto Internacional de Derechos Civiles y Políticos

STC : Sentencia del Tribunal Constitucional Español

TC : Tribunal Constitucional de Chile

TCE : Tribunal Constitucional Español

TEDH : Tribunal Europeo de Derechos Humanos

TPI : Tribunal Penal Internacional

UDI : Unión Demócrata Independiente 